\title{
New Approaches for Bioaugmentation as a Remediation Technology
}

\author{
TERRY J. GENTRY, CHRISTOPHER RENSING, and IAN L. PEPPER \\ Department of Soil, Water, and Environmental Science, University of Arizona, Tucson, \\ Arizona, USA
}

\begin{abstract}
Bioaugmentation is commonly employed as a remediation technology. However, numerous studies indicate that introduced microorganisms often do not survive in the environment and thus do not increase contaminant remediation. This review details several new approaches that may increase the persistence and activity of exogenous microorganisms and/or genes following introduction into the environment. These techniques include: (1) bioaugmentation with cells encapsulated in a carrier such as alginate; (2) gene bioaugmentation where the goal is for the added inoculant to transfer remediation genes to indigenous microorganisms; (3) rhizosphere bioaugmentation where the microbial inoculant is added to the site along with a plant that serves as a niche for the inoculant's growth; and (4) phytoaugmentation where the remediation genes are engineered directly into a plant for use in remediation without a microbial inoculant. Additionally, the review discusses the generation of genetically engineered microorganisms for use in bioaugmentation along with methods for the control of the engineered microorganisms in the environment, and the potential effects of the release on indigenous organisms. Various methods for the detection of introduced microorganisms such as real-time polymerase chain reaction (PCR) and reporter genes are also addressed. Ultimately, these new approaches may broaden the application of bioaugmentation as a remediation technology.
\end{abstract}

KEY WORDS: genetically engineered microorganism, immobilized cell, phytoaugmentation, phytoremediation, reporter gene, suicide gene

Address correspondence to Terry J. Gentry, at the current address, Oak Ridge National Laboratory, Environmental Sciences Division, PO Box 2008, Bldg 1505, MS-6038, Room 350, 1 Bethel Valley Road, Oak Ridge, TN 37831-6038, USA. E-mail: gentrytj@ornl.gov 


\section{INTRODUCTION}

\section{A. History of Bioaugmentation}

Bioaugmentation has been utilized in agriculture for many years. The inoculation of legumes with symbiotic, nitrogen-fixing Rhizobium spp. dates back to the 1800s. Attempts have also been made to utilize bioaugmentation with free-living or plant-associated nitrogen-fixing bacteria such as Azotobacter or Azospirillum spp. to increase plant yields. ${ }^{147,175}$ Other agricultural applications of bioaugmentation include inoculation of plant seeds with plantgrowth-promoting microorganisms or with plant-protecting microorganisms that are antagonistic to plant pathogens. ${ }^{15,88,157}$ Inoculation is also used to transform agricultural products into more useful forms such as the generation of silage from forages. ${ }^{227}$

More recently, bioaugmentation has been applied in attempts to remediate numerous environmental problems. Inoculants are commonly added to compost piles and septic tanks to expedite degradation. ${ }^{68}$ Bioaugmentation with microorganisms has been shown to increase degradation of numerous compounds including chlorinated solvents, methyl tert-butyl ether, nitrophenols, oil, pentachlorophenol, polychlorinated biphenyls, polycyclic aromatic hydrocarbons, and several pesticides such as atrazine, dicamba, and carbofuran. ${ }^{3,129,191,200,214}$ However, numerous other studies have demonstrated that bioaugmentation often does not result in increased contaminant remediation. ${ }^{3,26,152}$

\section{B. Problems Associated with Bioaugmentation}

Studies often observe that the number of exogenous microorganisms decreases shortly after addition to a site. There are several explanations for the death of introduced organisms, including both abiotic and biotic stresses. ${ }^{3}$ The abiotic stresses may include fluctuations or extremes in temperature, water content, $\mathrm{pH}$, and nutrient availability, along with potentially toxic pollutant levels in contaminated soil. ${ }^{221,243}$ In addition, the added microorganisms almost always face competition from indigenous organisms for limited nutrients, along with antagonistic interactions including antibiotic production by competing organisms, and predation by protozoa and bacteriophages.

It can also be difficult to deliver the inoculant to the desired location. ${ }^{55,222}$ This is not problematic for surface soils where the inoculant can be mechanically incorporated into the contaminated material, but in subsurface environments direct incorporation ranges from difficult to impossible. Technologies such as use of ultramicrobacteria, bacteria with altered cell surface properties, and/or addition of surfactants may facilitate greater transport through the soil matrix. ${ }^{188,222}$ The ability to distribute the inoculant also depends on what organism is being used. Fungi, which are larger than bacteria, are 
usually restricted to surface applications while bacteria are more adaptable to surface or subsurface applications.

Other researchers including Dejonghe et al., ${ }^{47}$ Pritchard, ${ }^{172}$ van Veen et al., ${ }^{243}$ and Vogel $^{245}$ have published reviews on bioaugmentation. Our goals for this review are to build on the foundation of the previous bioaugmentation reviews and to discuss new technologies, including: (1) novel methods to increase survival of microorganisms inoculated into contaminated sites; (2) the development of genetically engineered microorganisms with increased remediation capabilities; (3) use of reporter genes to monitor the activity and/or presence of introduced microorganisms; (4) use of suicide genes to control the spread of genetically engineered microorganisms; and (5) plant-based technologies for delivering remediation genes to a contaminated site.

\section{CELL BIOAUGMENTATION}

\section{A. Carrier and Encapsulation Technologies for Inoculant Delivery}

1. USE OF CARRIER MATERIALS FOR BIOAUGMENTATION

Several different techniques have recently been developed for bioaugmenting environmental sites (Figure 1 and Table 1), but microbial inoculants have historically been applied to the soil as live microorganisms in either a liquid culture or attached to a carrier material. ${ }^{167}$ When applying the inoculant to a harsh environment such as soil, it may be desirable to use a carrier material since it can provide a protective niche and even temporary nutrition for the introduced microorganism. ${ }^{243}$ Numerous different carrier materials have been used including biosolids, charcoal-amended soil, clay, lignite, manure, and peat. ${ }^{11,13,104,113,164,243}$ Most of the research on the different carrier materials

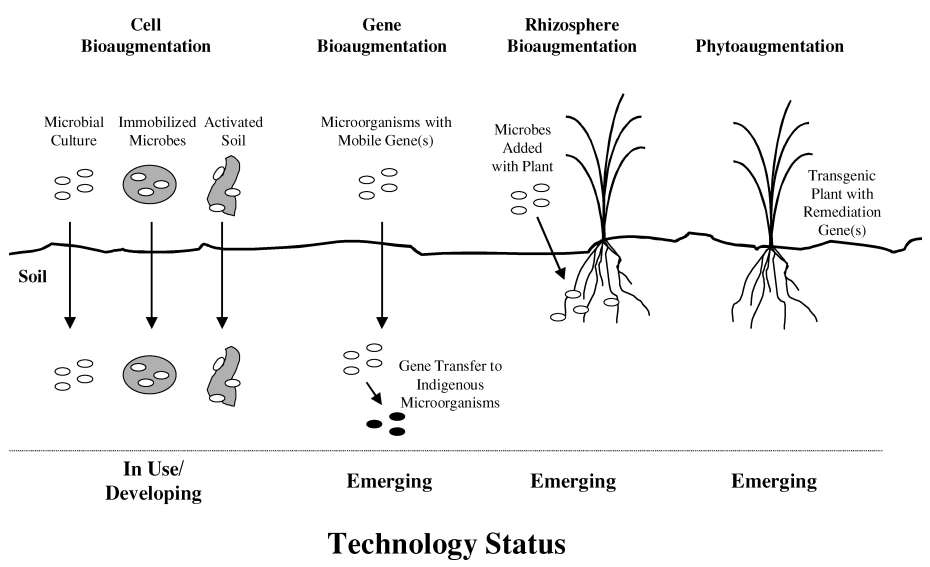

FIGURE 1. Overview of different technologies for delivering remediation genes to contaminated sites. 
TABLE 1. Selected Research Articles Detailing the Different Approaches for Use of Bioaugmentation as a Remediation Technology

\begin{tabular}{|c|c|c|c|}
\hline $\begin{array}{l}\text { Bioaugmentation } \\
\text { approach }\end{array}$ & Organism(s) used & Contaminant(s) & Reference \\
\hline \multicolumn{4}{|l|}{ Cell } \\
\hline \multirow[t]{2}{*}{ Culture } & Comamonas testosteroni BR60 & 3-Chlorobenzoate & 77 \\
\hline & $\begin{array}{l}\text { Ralstonia eutropha JMP134 } \\
\text { and Pseudomonas strain H1 }\end{array}$ & $\begin{array}{l}\text { Cadmium and } \\
\text { 2,4-dichlorophenoxyacetic } \\
\text { acid }\end{array}$ & 181 \\
\hline \multirow[t]{4}{*}{ Immobilized } & Alcaligenes faecalis & Phenol & 10 \\
\hline & Mixed microbial culture & 2,4-dichlorophenol & 173 \\
\hline & Pseudomonas sp. UG14Lr & Phenanthrene & 250 \\
\hline & $\begin{array}{l}\text { Flavobacterium sp. and } \\
\text { Rhodococcus } \\
\text { chlorophenolicus PCP-1 }\end{array}$ & Pentachlorophenol & 28 \\
\hline \multirow[t]{3}{*}{ Activated Soil } & Indigenous microorganisms & Pentachlorophenol & 9 \\
\hline & Indigenous microorganisms & Atrazine & 189 \\
\hline & Indigenous microorganisms & 2-, 3-, and 4-Chlorobenzoate & 76 \\
\hline \multirow[t]{4}{*}{ Gene } & Ralstonia eutropha JMP134 & $\begin{array}{l}\text { 2,4-Dichlorophenoxyacetic } \\
\text { acid }\end{array}$ & 53 \\
\hline & $\begin{array}{l}\text { Ralstonia eutropha JMP134 } \\
\text { and E. coli D11 }\end{array}$ & $\begin{array}{l}\text { 2,4-Dichlorophenoxyacetic } \\
\text { acid }\end{array}$ & 155 \\
\hline & Comamonas sp. rN7(R503) & Phenol & 249 \\
\hline & Pseudomonas putida UWC3 & $\begin{array}{l}\text { 2,4-Dichlorophenoxyacetic } \\
\text { acid }\end{array}$ & 48 \\
\hline \multirow[t]{4}{*}{ Rhizosphere } & $\begin{array}{l}\text { Pinus sylvestris and Suillus } \\
\text { variegatus }\end{array}$ & 2,4-Dichlorophenol & 139 \\
\hline & $\begin{array}{l}\text { Triticum aestivum and } \\
\text { Pseudomonas fluorescens }\end{array}$ & Trichloroethylene & 261 \\
\hline & $\begin{array}{l}\text { Elymus dauricus and } \\
\text { Pseudomonas spp. }\end{array}$ & 2-Chlorobenzoate & 208 \\
\hline & $\begin{array}{l}\text { Bromus erectus Huds. and } \\
\text { Pseudomonas sp. Strain I4 }\end{array}$ & 2,4,6-Trinitrotoluene & 212 \\
\hline \multirow[t]{6}{*}{ Phytoaugmentation } & Oryza sativa & 3-Chlorocatechol & 207 \\
\hline & Arabidopsis thaliana & Methylmercury & 18 \\
\hline & Arabidopsis thaliana & Arsenic & 51 \\
\hline & Nicotiana glauca & Lead & 78 \\
\hline & Nicotiana tabacum & Copper & 231 \\
\hline & Nicotiana tabacum & Trinitrotoluene & 72 \\
\hline
\end{tabular}

has been for agricultural legume inoculants, with peat being the most commonly used. ${ }^{164,243,244}$

Research has indicated that presterilization of the carrier can increase the inoculant's shelf life. ${ }^{228}$ The results of Van Dyke and Prosser ${ }^{242}$ also demonstrate that preincubation of the inoculant in a sterile carrier can enhance its ultimate survival in environment. The researchers added a Pseudomonas fluorescens strain to soil either as a liquid culture, in a sterile soil carrier, or in a nonsterile soil carrier. The bacteria introduced via the sterile soil demonstrated enhanced survival as compared to the other treatments. After $28 \mathrm{~d},<10^{3} \mathrm{CFU} / \mathrm{g}$ of the $10^{7} \mathrm{CFU} / \mathrm{g}$ of introduced bacteria remained in the 
microcosms amended with the liquid inoculant and nonsterile soil inoculant, as compared to $>10^{4}$ CFU of introduced bacteria per gram in microcosms amended with the sterile soil inoculant. The authors also included treatments where $P$. fluorescens was inoculated in sterile soil, incubated for 7 or $14 \mathrm{~d}$, and then used as the bioaugmentation inoculant. Interestingly, the longer $P$. fluorescens was incubated in the sterile soil, the better it survived when added to the target, nonsterile soil. The researchers theorized that growth of $P$. fluorescens in the sterile soil may have allowed the strain to adapt to the soil environment prior to encountering competition from indigenous microorganisms when added to the nonsterile soil.

The ideal characteristics for a carrier material as listed by van Veen et al. ${ }^{243}$ include: (1) providing an adequate environment for cell survival and growth resulting in a long shelf life and enhanced activity when added to the environment; (2) being nontoxic to the inoculant microorganisms and the environment; and (3) allowing targeted introduction of cells and also a means to contain the introduced microorganisms when control is necessary. All of the different materials listed earlier could potentially increase the inoculant's shelf life. However, biosolids and manure may introduce pathogens (unless sterilized) or other contaminants into the environment, and none of these materials would be effective at restricting the spread of the inoculant.

\section{BIOAUGMENTATION WITH ENCAPSULATED MICROORGANISMS}

Several other materials including acrylate copolymers, agarose, alginate, gelatin, gellan gum, kappa-carrageenan, polyurethane, and polyvinyl alcohol gel have been developed to encapsulate or immobilize cells for various purposes. ${ }^{75,85,141,149,165,173,203}$ Recently, researchers have investigated the use of these compounds to encapsulate microorganisms for introduction into soil or water. ${ }^{236,243}$ The different materials have varying characteristics and degrees of recalcitrance that may or may not be beneficial depending on the application $^{24}$ (Table 2). Alginate is the most commonly investigated carrier for bioremediation applications, and has been used with numerous contaminants including chromium, cresol, nitrate, pentachlorophenol, phenanthrene, phenol, phosphate, and 2,4,6-trichlorophenol. ${ }^{10,28,73,75,87,141,166,206,250}$ Alginate may also have potential for delivery of naked DNA directly into the environment for the purpose of gene bioaugmentation, ${ }^{1}$ which is discussed in a later section.

As pointed out by van Veen et al., ${ }^{243}$ the use of these materials allow the microorganisms to be contained in a relatively non-toxic matrix through which gases and liquids can diffuse. The capsule matrix can buffer the introduced microorganisms against pollutant toxicity in the environment. ${ }^{10,149}$ Additionally, substrates or $\mathrm{C}$ compounds can be added to the capsule to confer an advantage to the embedded inoculant; ${ }^{236}$ however, Duquenne et al. ${ }^{62}$ reported that diffusion of growth substrates from the capsule into the surrounding environment can diminish the positive effect. The capsule may 
TABLE 2. Properties of Various Materials Used to Encapsulate Inoculants

\begin{tabular}{|c|c|c|c|}
\hline Material & Description & Notable properties & Reference \\
\hline Alginate & $\begin{array}{l}\text { Linear polymer comprised of } \\
\text { mannuronic and guluronic } \\
\text { acid monomers. Produced } \\
\text { by algae and several } \\
\text { bacteria. Solidified by } \\
\text { cross-linking with } \mathrm{Ca}^{2+} \text { ions. }\end{array}$ & $\begin{array}{l}\text { Nontoxic, biodegradable. } \\
\text { Commonly used } \\
\text { encapsulating material. }\end{array}$ & 10 \\
\hline Carrageenan & $\begin{array}{l}\text { Comprised of galactose } \\
\text { monomers that differ in } \\
\text { degree of sulfonation. } \\
\text { Produced by algae. } \\
\text { Extrusion into } \mathrm{K}^{+} \text {ions } \\
\text { strengthens gel. }\end{array}$ & $\begin{array}{l}\text { Nontoxic, biodegradable. } \\
\text { Cell exposure to }>35^{\circ} \mathrm{C} \\
\text { during some } \\
\text { encapsulation processes } \\
\text { may harm } \\
\text { microorganisms. }\end{array}$ & 75 \\
\hline Polyacrylamide & $\begin{array}{l}\text { Synthetic polymer formed by } \\
\text { crosslinking acrylamide } \\
\text { monomers using } \\
\text { bisacrylamide. }\end{array}$ & $\begin{array}{l}\text { More stable, not readily } \\
\text { degradable, but } \\
\text { acrylamide monomer is } \\
\text { toxic. }\end{array}$ & 236 \\
\hline $\begin{array}{l}\text { Polyvinyl } \\
\text { alcohol gel }\end{array}$ & $\begin{array}{l}\text { Synthetic gel. Polyvinyl } \\
\text { alcohol may be mixed with } \\
\text { alginate and cross-linked } \\
\text { with } \mathrm{Ca}^{2+} \text { ions. }\end{array}$ & $\begin{array}{l}\text { Nontoxic, not readily } \\
\text { degradable. Forms very } \\
\text { elastic gel. }\end{array}$ & 173 \\
\hline
\end{tabular}

also protect the inoculant from indigenous microorganisms as evidenced by prevention of phage $\Phi$ R2f lysis of alginate-encapsulated Pseudomonas fluorescens. ${ }^{216}$

Another potential benefit of the encapsulation technology is the ability to create microsites with a unique microbial community that works interactively to remediate a given compound. Hajji et al. ${ }^{87}$ used an alginateencapsulated methanogenic consortium to remediate $o$-cresol, $p$-cresol, and phenol contaminated sludges. Total removal of phenol occurred in less than $40 \mathrm{~d}$ following the addition of the encapsulated organisms, as compared to $171 \mathrm{~d}$ in the control without the consortium. Similar effects were seen for $o$ - and $p$-cresol, although both compounds took longer to degrade than did the phenol. Additionally, Vassilev et al. ${ }^{244}$ demonstrated the utility of encapsulated, mixed microbial cultures for rhizosphere bioaugmentation. The researchers inoculated soil with the arbuscular mycorrhizae Glomus deserticola and the P-solubilizing yeast Yarowia lipolytica. The microorganisms were applied to the soil either as free cultures, in alginate alone, or in alginate together. Treatments receiving the coencapsulated strains had increased plant dry weights, soluble P levels, and levels of mycorrhizal colonization. The authors concluded that the yeast had functioned as a "mycorrhizae helper microorganism."

\section{ACTIVATED SOIL BIOAUGMENTATION}

Another approach to cell bioaugmentation is to use activated soil directly as both the inoculant and carrier without extracting the degraders from the 
soil. ${ }^{9,47,76,189}$ Activated soil is defined as soil that has been exposed to the contaminant of interest and contains a developed degrader population that can eliminate the contaminant. The use of activated soil for bioaugmentation has the appearance of being less scientific than other methods but has the potential advantages of: (1) introduction of a naturally developed degrader population(s) that may be composed of several members or even consortia that would not be as effective if they were isolated and applied to the site as pure cultures; (2) the degraders are not cultured outside of the soil and thus do not lose their ability to compete in the environment as is often observed for lab-cultured strains; and (3) potential inclusion of unculturable degraders that would be missed in attempts to isolate and culture an organism from one site in order to introduce the organism to another site. ${ }^{76}$ Activated soil also provides many of the benefits of materials such as peat and alginate as described in the previous sections. ${ }^{9}$

Barbeau et al. ${ }^{9}$ used activated soil to remediate pentachlorophenol (PCP)-contaminated soil. The researchers collected two different PCPcontaminated soils from a wood-mill site and a treated-pole storage site. Soil 2 degraded PCP and was used for the bioaugmentation inoculant, while Soil 1 did not degrade PCP and was bioaugmented. The activated soil inoculant was prepared by incubating Soil 2 in a soil slurry bioreactor for $31 \mathrm{~d}$. Progressively increased levels of PCP (up to $300 \mathrm{mg} / \mathrm{L}$ ) were added to the bioreactor during the incubation. The activated Soil 2 was then used to bioaugment Soil 1 resulting in addition of $10^{5} \mathrm{CFU}$ of PCP degraders/g bioaugmented soil. The PCP concentration in Soil 1 bioaugmented with activated Soil 2 decreased from $400 \mathrm{mg} / \mathrm{kg}$ to $5 \mathrm{mg} / \mathrm{kg}$ within $130 \mathrm{~d}$, while PCP concentrations remained unchanged in the nonbioaugmented soil.

Despite the potential benefits, there can be disadvantages to the use of carriers, encapsulated cells, or activated soils for bioaugmentation. These technologies are more suited to surface applications due to the probability that microbial encapsulation in, or attachment to, larger particles may further impede their movement through soil or sediment. ${ }^{150}$ Depending on the environmental conditions, microorganisms, and encapsulating material used, adverse conditions may develop within the capsule, such as the accumulation of toxic compounds or anoxic conditions, which may inhibit or kill the inoculant. ${ }^{149,251}$ It is therefore critical to match the appropriate carrier technology with the specific conditions of the contaminated site. More thorough discussions on environmental applications of carriers and encapsulated cells can be found in Cassidy et al. ${ }^{36}$ and Trevors et al. ${ }^{236}$

\section{B. Methods to Increase Microbial Transport Following Bioaugmentation}

As discussed in the previous sections, it can be difficult to introduce and disperse microorganisms through the subsurface due to microbial 
sorption and physical straining by soil solids. ${ }^{55,218,222}$ Techniques that researchers have investigated in order to increase microbial transport include the use of adhesion-deficient bacteria, ${ }^{55,222}$ ultramicrobacteria, ${ }^{33,122,188}$ and surfactants. ${ }^{29,131}$ Streger et al. ${ }^{222}$ developed an adhesion-deficient strain of the methyl tert-butyl ether degrader Hydrogenophaga flava ENV735 by sequentially passing a culture through sterile sediment 27 times. While $>99.5 \%$ of the cells were initially retained in the sediment, only $39 \%$ of the cells adhered to the sediment after 27 passes. In sand column studies, a maximum concentration of $10^{7}$ adhesion-deficient cells $/ \mathrm{ml}$ eluted, in contrast to $10^{4}$ wild-type cells $/ \mathrm{ml}$ that eluted. The results were even more dramatic for sediment columns, with $10^{7}$ adhesion-deficient cells/ml eluting in contrast to no wild-type cells being detected even after 6 pore volumes of flow through. Further analysis indicated that the cell surface of the adhesion-deficient strain was much more hydrophilic than that of the wild-type strain, thus facilitating enhanced transport. The researchers also found that a $0.1 \%$ concentration of the surfactant Tween 20 reduced adhesion of the wild-type cells to a sand column and increased transport 28\%. Other researchers have starved cells in order to reduce their cell size and potentially increase transport. ${ }^{33,122}$ Use of motile inoculants that can migrate toward contaminants may also enhance remediation. $^{258}$

While these different techniques have great promise for enhancing the transport of inoculants, the selection of adhesion-deficient strains or generation of ultramicrobacteria may result in cultures with reduced contaminantdegrading capabilities, especially if the remediation genes are plasmid encoded, unless this selective pressure is maintained during the process. ${ }^{222}$ Additionally, many surfactants may be toxic to the microorganisms. ${ }^{222}$

\section{Use of Multiple Cultures for Bioaugmentation}

Sites contaminated with several different chemicals present special problems for bioaugmentation. ${ }^{167}$ In such cases, it may be necessary to use multiple microbial cultures or consortia for bioaugmentation. ${ }^{181,241}$ An example of this situation is soil cocontaminated with metals and organics. Roane et al. ${ }^{181}$ used a dual-bioaugmentation strategy to remediate soil contaminated with both $\mathrm{Cd}$ and 2,4-dichlorophenoxyacetic acid (2,4-D). The researchers inoculated the soil with the metal-resistant bacterium Pseudomonas strain H1 and/or the 2,4-D-degrading bacterium Ralstonia eutropha JMP134. Bioaugmentation with both Pseudomonas strain H1 and R. eutropha JMP134 increased 2,4-D degradation in the presence of $\mathrm{Cd}$, as compared to microcosms not bioaugmented or bioaugmented with only one strain. Another interesting point from this paper is that the authors added the Pseudomonas strain H1 48 h before adding the $R$. eutropha JMP134. It was hypothesized that by staggering the bioaugmentation, the metal-resistant Pseudomonas strain H1 was 
able to partially detoxify the Cd (reportedly by intracellular sequestration) prior to introduction of the Cd-sensitive $R$. eutropha JMP134.

\section{GENE BIOAUGMENTATION}

Since introduced microorganisms often do not survive following bioaugmentation, scientists have investigated the use of naturally occurring horizontal gene transfer processes for introduction of remediation genes into a contaminated site. Recent advances in genome sequencing are revealing the large role that horizontal gene transfer has played in microbial development and adaptation in the environment. ${ }^{159}$ Horizontal gene transfer may occur via uptake of naked DNA (transformation), mediation by bacteriophage (transduction), or physical contact and exchange of genetic material such as plasmids or conjugative transposons between microorganisms (conjugation).

The potential advantages for use of gene bioaugmentation, where the remediation genes are in a mobile form such as a self-transmissible plasmid, over the traditional cell bioaugmentation approaches are: (1) introduction of remediation genes into indigenous microorganisms that are already adapted to survive and proliferate in the environment; and (2) no requirement for long-term survival of the introduced host strain. The transfer of plasmids, via conjugation, is the technology most studied with respect to bioaugmentation. ${ }^{39,48,53,93,155,156,233,234,235}$

Newby et al. ${ }^{155}$ compared bioaugmentation with two different bacterial donors for delivering the self-transmissible plasmid pJP4, containing 2,4-D degradative genes, to indigenous soil bacteria. The pJP4 plasmid was delivered to the soil either in its original host, $R$. eutropha JMP134, or in E. coli D11. ${ }^{156}$ The R. eutropha JMP134 was capable of mineralizing 2,4-D, but E. coli D11 was not because it lacked the chromosomal genes that, along with the plasmid genes, allow for complete mineralization of 2,4-D. Accordingly, 2,4D was degraded within $28 \mathrm{~d}$ in the soil receiving the $R$. eutropha JMP134, but took $49 \mathrm{~d}$ to degrade in the nonbioaugmented soil and soil receiving the $E$. coli D11 inoculant. Most of the 2,4-D degraders isolated from the soil receiving $R$. eutropha JMP134 were identified as the inoculant organisms, while numerous transconjugants were detected in the E. coli D11 amended soil. Following degradation of the initial 2,4-D amendment, the authors added additional 2,4-D to the soil. After the reamendment, 2,4-D was degraded more rapidly in the microcosms that received the $E$. coli D11 inoculant than the soil that received the $R$. eutropha JMP134 inoculant and non-bioaugmented soil. These results indicate the potential for indigenous microorganisms to degrade specific contaminants if furnished with the necessary genetic material via gene bioaugmentation. The data also illustrate the potential for bioaugmentation to alter the indigenous soil microbial gene pool.

Other researchers have also found similar results. Dejonghe et al. ${ }^{48}$ investigated the dissemination of two different 2,4-D degradation plasmids in both 
the A (upper) and B (lower) horizons of a soil. Addition of an auxotrophic Pseudomonas putida strain containing either of the two plasmids resulted in large populations of transconjugants $\left(>10^{5} / \mathrm{g}\right)$ in both the A and B horizons. Donor populations decreased following addition to the soil, while the development of transconjugant populations correlated with the degradation of 2,4-D. However, bioaugmentation only resulted in enhanced 2,4-D degradation in the $\mathrm{B}$ horizon that did not have an indigenous degrader population and not the A horizon, which did contain an indigenous degrader population. Gene bioaugmentation may also have applications for metal contaminated sites. ${ }^{56} \mathrm{~A}$ more thorough review of the use of mobile genes in bioaugmentation can be found in Top et al. ${ }^{234}$

Another point to consider when planning the use of gene bioaugmentation technology is that the U.S. Environmental Protection Agency (EPA) may make a regulatory distinction between different hosts of the same plasmid even if neither is genetically engineered. ${ }^{239}$ The U.S. EPA considers microorganisms formed by combining genetic material from organisms in different genera to be "new" organisms, which are regulated under the Toxic Substances Control Act (TSCA). For organisms containing mobile genetic elements such as plasmids, the U.S. EPA considers the recipient microorganism to be "new" and thus regulated under TSCA if the mobile genetic element was first identified in a microorganism from a different genus. For example, of the two pJP 4 hosts used by Newby et al., ${ }^{155}$ the E. coli D11 would be covered under these regulations even though the plasmid was transferred from R. eutropha JMP134 (the first identified host of pJP4) to E. coli D11 through a naturally occurring process. Not all countries make this distinction, and some exclude naturally occurring processes such as mating and/or natural recombination from processes that, in legal terms, produce genetically modified organisms. ${ }^{67}$

In order to potentially avoid such regulations, it would be preferable to use the original host for bioaugmentation unless there is compelling need for another host. In fact, of the experiments described in this section, the donors other than $R$. eutropha JMP134 were chosen for their inability to degrade the contaminant and/or survive following bioaugmentation thus reducing their interference with the detection of transconjugants. While this may be desirable for certain laboratory studies, a donor microorganism that can both degrade the contaminant and transfer degradative genes is potentially more suited to field application.

\section{BIOAUGMENTATION WITH MICROBIAL-DERIVED MATERIALS}

Another bioaugmentation approach is to add microbial products, such as biosurfactants or enzymes, directly as an amendment either alone or in combination with a microbial inoculant. Biosurfactants have been used for 
bioremediation of metal and organic-contaminated material, ${ }^{74,97,134,137,193,204}$ and they may also have a utility in bioaugmentation applications either to protect a microbial inoculant from metal toxicity or to increase the amount of organic substrates available for degradation. ${ }^{174,193}$ Sandrin et al. ${ }^{193}$ investigated the use of the metal-complexing biosurfactant rhamnolipid for decreasing metal toxicity in a model cocontaminated system. The system contained Cd and naphthalene and was inoculated with a naphthalene-degrading Burkbolderia sp. The authors found that rhamnolipid eliminated Cd toxicity when added at a 10-fold higher concentration than the Cd. At lower concentrations, the rhamnolipid either only reduced or had no impact on Cd toxicity. The authors concluded that rhamnolipid decreased Cd toxicity through metal complexation and LPS release, and possibly increased naphthalene bioavailability.

Other researchers have used enzymes, either purified or encapsulated in dead microbial cells, for contaminant remediation. ${ }^{17,223,262,266}$ Strong et al. ${ }^{223}$ bioaugmented atrazine-contaminated soil with a genetically engineered $E$. coli strain that overproduced the atrazine chlorohydrolase enzyme responsible for dechlorinating atrazine. The researchers chemically killed the genetically engineered microorganisms (GEMs) prior to addition to a field site reducing regulatory concerns. ${ }^{246}$ After $8 \mathrm{wk}$, atrazine concentrations in the enzyme-treated plots had decreased $52 \%$ in contrast to insignificant degradation in the control plots. The use of these derived-materials may avoid some of the difficulties often associated with bioaugmentation, such as the need for survival of live microbial inoculants in harsh field environments. However, there still may be problems with biosurfactant toxicity ${ }^{199}$ and effectiveness, ${ }^{46}$ along with the potential hazards inherent in delivery of enzymes to the subsurface while attempting to minimize enzymatic sorption to soil solids and/or inactivation.

\section{GENETICALLY ENGINEERED MICROORGANISMS (GEMs)}

\section{A. Enhancement of Contaminant Degradation Genes}

In the previous sections, we have discussed different approaches for the addition of microorganisms to a contaminated site. As has been briefly mentioned in previous sections, it is also possible to increase the remediation potential of microorganisms through genetic engineering prior to their use for bioaugmentation. Recent advances in molecular biology have enabled numerous technologies for engineering or enhancing remediation genes. To date, the environmental release of GEMs has mostly been for agricultural purposes, but at least one bioremediation release has occurred. ${ }^{5,180}$ A thorough discussion of all the technologies to generate GEMs is beyond the scope of 
this review, but we present a concise description of two major methods to engineer remediation genes: (1) gene introduction, and (2) gene alteration. ${ }^{80}$

\section{GENE INTRODUCTION}

Specific remediation genes can be introduced into plasmids or the chromosome of the target microorganism. ${ }^{80,201}$ The most straightforward way to increase the genetic content of a microorganism is to add a plasmid containing the desired gene. This transfer can be accomplished with naturally occurring plasmids, if they are transmissible, by mating a donor microorganism with a target microorganism. ${ }^{156,217}$ This process does not involve any recombinant DNA techniques and commonly occurs in nature. ${ }^{156}$ When an appropriate naturally occurring plasmid is not available, it may be necessary to clone the gene into a broad-host-range plasmid, which is then added to the donor microorganism either through conjugation or transformation. ${ }^{83,128}$

It may be desirable to incorporate the gene into the host chromosome in order to reduce the potential for transfer of the gene to other microorganisms in the environment. The mini-Tn 5 transposon system is commonly used to insert genes into gram-negative bacteria. ${ }^{44,92}$ A system based on Tn5 is even commercially available (Epicentre, Madison, WI). The original miniTn 5 transposon system is constructed as a plasmid with a selectable marker (such as antibiotic resistance), a suicide function for counterselection, and a multiple cloning site for insertion of foreign DNA via recombinant DNA techniques. ${ }^{192}$ Once the recombinant plasmid is added to the target organism, the transposon containing the added gene incorporates into the chromosome of a portion of the target bacteria. These GEMs are then selected for based on the incorporated phenotypic trait. Wantanabe et al. ${ }^{249}$ used this approach to introduce a phenol-degradative gene into an environmental isolate for subsequent use in bioaugmentation. The researchers isolated the phenoldegrading bacterium Comamonas sp. rN7 from activated sludge. The Comamonas sp. rN7 was the dominant phenol-degrading population in the sludge, but was not as efficient at phenol degradation as were other strains such as Comamonas testosteroni R5. The authors initially attempted to bioaugment the sludge with $C$. testosteroni $\mathrm{R} 5$ but without success. ${ }^{248}$ They then isolated the phenol-degradative genes from $C$. testosteroni R5, and introduced the genes into the chromosome of Comamonas sp. rN7 via a mini-Tn 5 construct to create Comamonas sp. rN7(R503). ${ }^{249}$ The authors then amended the activated sludge with C. testosteroni R5, Comamonas sp. rN7, or Comamonas sp. rN7(R503). The gene-augmented strain Comamonas sp. rN7(R503) survived in the sludge better than $C$. testosteroni $\mathrm{R} 5$ and resulted in improved resistance to phenol shock when compared to all other treatments.

The disadvantages of the mini-Tn5 system are that (1) it incorporates randomly into the host chromosome, possibly inactivating vital genes, and (2) it contains antibiotic resistance genes that may ultimately hinder the environmental release of constructed GEMs. ${ }^{201}$ Different systems have been 
developed that can potentially eliminate some of these problems. Koch et al. ${ }^{111}$ developed a Tn7-based system that incorporates at a specific chromosomal site in gram-negative bacteria. Hoang et al. ${ }^{95}$ constructed a system based on a phage attachment site that enables site-specific integration in Pseudomonas aeruginosa (and possibly other Pseudomonas spp.) and also allows removal of antibiotic resistance genes in vivo.

\section{GENE ALTERATION}

It is also possible to alter selected genes for optimal activity under different environmental conditions. ${ }^{80}$ While gene alteration has been applied more often for industrial or agricultural applications, ${ }^{14,124,126,224}$ it can also be useful for bioremediation processes. ${ }^{30,37,125,225}$ Traditionally, the gene of interest is first cloned into a vector for maintenance in a laboratory organism, such as $E$. coli, that is more amenable to laboratory growth and manipulation. ${ }^{192}$ The factors that can be altered in order to increase gene expression include: (1) transcriptional promoter and terminator sequences; (2) number of copies of the gene in the host organism; and 3) stability of the cloned gene protein. ${ }^{80}$ The gene is then altered and ultimately reintroduced into the desired microorganisms as discussed in the previous section.

A classic example of gene alteration for enhanced contaminant degradation is the research of Ramos et al. ${ }^{176}$ The Pseudomonas putida soil isolate containing plasmid pWWO was capable of degrading several compounds including toluene and xylene; however, it could not degrade 4-ethylbenzoate (4-EB) despite having all of the functional genes necessary for the metabolizing the chemical, because 4-EB was incapable of inducing the degradative pathway. ${ }^{125}$ The researchers first cloned the $x y l S$ regulatory gene into $E$. coli and then generated a mutant gene that responded to the presence of 4-EB. Introduction of the mutant gene back into the Pseudomonas isolate enabled the strain to transform 4-EB, although it could not grow on the compound due to another enzymatic bottleneck lower in the pathway. The mutant $x y l S$ gene was also induced at higher levels in E. coli than in P. putida which the authors attributed to interference by the wild-type $x y l S$ gene in $P$. putida.

The approach above is very useful for alteration of genes that will ultimately be used in laboratory or industrial microbial strains; however, genes that are optimized in laboratory strains may not function at the same level in environmental isolates. ${ }^{31,35,257}$ Ohtsubo et al. ${ }^{162}$ used an in situ, homologous recombination approach, which avoided culture of degradative genes in laboratory strains, to increase the activity of biphenyl-degradative genes in Pseudomonas sp. KKS102. The researchers replaced the native biphenyl promoter in Pseudomonas sp. KKS102 with several different constitutive promoters in situ via homologous recombination. All of the constitutive promoters resulted in increased biphenyl degradation and decreased catabolite repression of the biphenyl pathway. This strategy could be applied to genes in 
other bacterial strains, if they are amenable to homologous recombination, even without detailed knowledge of the gene's regulation.

\section{B. Control of GEMs Released into the Environment}

Even though GEMs with significant remediation capabilities can be constructed, it is difficult to obtain regulatory approval for their ultimate release into the environment. In the United States, there have only been 11 TSCA microbial environmental release applications filed with the U.S. EPA since 1998, with most of these being for Bradyrbizobium japonicum strains. ${ }^{238}$ In fact, to our knowledge, only one field release of a GEM for bioremediation has occurred in the United States. ${ }^{197}$ The concern is regarding the potential for GEMs to persist at a site, post-bioremediation, and/or for engineered genes in GEMs to be transferred to indigenous organisms, resulting in unforeseeable consequences. ${ }^{7,70,144}$ The risk of gene transfer may be reduced by incorporating the engineered genes into the microbial chromosome instead of a plasmid, but it cannot be totally eliminated due to mobilization of chromosomal DNA by various naturally occurring processes. ${ }^{178}$

The most commonly studied approach for control of GEM survival in the environment is the incorporation of an inducible suicide gene into the microorganism. The suicide gene is activated when the target contaminant is eliminated, and there is therefore no more need for the presence of the GEM. Several different suicide genes have been studied, including those encoding DNases and RNases ${ }^{2,52}$; bacteriophage lysis genes ${ }^{109,183}$; agents that block essential metabolic enzymes ${ }^{105,226}$; and cell membrane-destabilizing genes. ${ }^{12,41,82,101,110,146,171,185}$

One of the early conditional-suicide systems was developed by Contreras et al. ${ }^{41}$ This elegant system was based on two elements contained on separate plasmids: (1) a fusion between the Pseudomonas putida promoter $\mathrm{P}_{\mathrm{m}}$, from the TOL plasmid meta-cleavage pathway, and the gene for the Lac repressor (lacI) from $E$. coli along with the gene for positive regulation of $\mathrm{P}_{\mathrm{m}}(x y l S)$; and (2) a fusion between the $\mathrm{P}_{\mathrm{tac}}$ promoter and the gef gene from $E$. coli that produces a porinlike protein that can kill the host by destabilizing the cell membrane (Figure 2). When XylS effectors, such as 3-methylbenzoate (3MB), are present, XylS is produced and positively regulates production of the Lac repressor resulting in negative regulation of the $\mathrm{P}_{\mathrm{tac}}$ promoter and thus no Gef production. In contrast, when the effector $(3 \mathrm{MB})$ is not present as would be the case when bioremediation is complete, the Lac repressor is not produced, allowing transcription of the gef gene and activity of the killing function. The system killed the vast majority of the host microorganisms in the absence of the appropriate effector compound, but the survival frequency was in the range of $10^{-5}$ to $10^{-6}$ per cell in a generation. The system was later improved by incorporating the suicide gene cassette into the host chromosome via a mini-Tn 5 transposon. ${ }^{101}$ The presence of two 


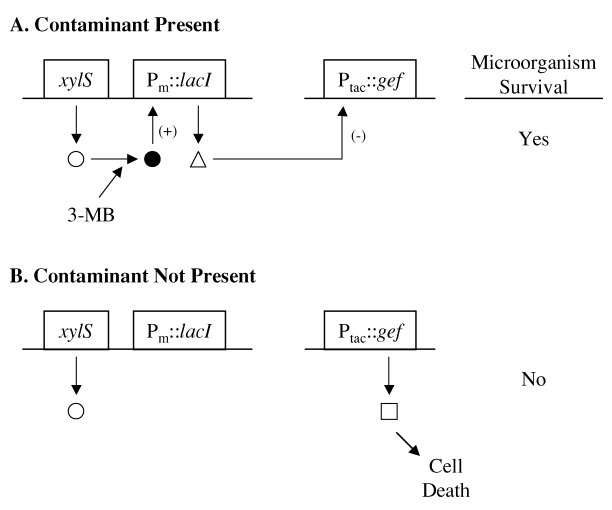

FIGURE 2. Conditional suicide system devised by Contreras et al. ${ }^{41}$ for control of genetically engineered microorganisms released into the environment. (A) In the presence of the inducer contaminant, 3-methylbenzoate (3-MB), production of the LacI repressor blocks Gef production. (B) When the contaminant is completely degraded, the Gef protein is produced resulting in cell death. Figure adapted from Contreras et al. ${ }^{41}$

copies of the suicide cassette on a bacterium's chromosome reduced the rate of kill-resistant mutants to as low as $10^{-8}$ per cell in a generation. A likely cause of mutations in this suicide system is the leaky repression of $\mathrm{P}_{\mathrm{tac}}$ by the Lac repressor. This would result in small, constitutive levels of Gef production, which would serve as positive selection pressure for kill-resistant mutants. Szafranski et al. ${ }^{226}$ achieved approximately the same frequency of kill-resistant mutant formation $\left(10^{-7}\right.$ to $10^{-8}$ per cell in a generation) with a plasmid system based on the above model by including a dual control mechanism that reduced leaky expression of the suicide gene. It may be possible to further decrease the rate of kill-resistant mutant formation by using multiple suicide systems with independent regulation systems in a given organism. ${ }^{110}$ Ronchel and Ramos ${ }^{184}$ improved killing by the gef-based system, initially devised by Contreras et al., ${ }^{41}$ by using a $\Delta$ asd mutant host strain that had the asd gene (which produces an intermediate in the biosynthesis of amino acids including lysine and methionine) inserted under the control of the $\mathrm{P}_{\mathrm{m}}$ promoter. The engineered strain would only grow on complex media or in the presence of compounds such as 3-methylbenzoate that induce $\mathrm{P}_{\mathrm{m}}$ transcription. By using this dual containment system, the researchers found that the number of bacteria that escaped killing after release into the environment was below the limit of detection $\left(<10^{-9}\right.$ mutants/cell in a generation).

Additionally, bacteriophages may be useful for containment of GEMs. Smit et al. ${ }^{216}$ added $P$. fluorescens $\mathrm{R} 2 \mathrm{f}$ encapsulated in alginate to soil along with phage $\Phi$ R2f. The phage did not impact bacterial numbers in the alginate, but it decreased the number of $P$. fluorescens R2f that developed outside of the alginate matrix by a factor of up to $10^{3}$. This level of control is not as high as that for the suicide genes, but it indicates the potential for combination of different methods to contain introduced GEMs. 
This study was also interesting since it combined use of an alginate carrier, which may be an effective method for GEM introduction into a harsh environment as previously discussed, along with control of the introduced organism. Despite the potential of these containment systems, it would be practically impossible, due to the fluid nature of microbial genomes, to develop a suicide system where no GEMs survive at a site after bioremediation is complete, and where there is no potential for transfer of engineered genes to indigenous organisms. The decision to release a GEM into the environment is ultimately a regulatory decision based on the balance between the potential benefits of the release, and the risk that the GEM will persist in the environment or transfer its genes to the indigenous organisms.

\section{PHYTOREMEDIATION}

\section{A. Use of Plant-Associated Microorganisms for Contaminant Remediation}

A developing approach for bioaugmentation is to add the microbial inoculant to the soil along with a plant that supports the inoculant's growth. The use of plants for remediation, or phytoremediation, is a relatively new technology. Phytoremediation has generated much interest because it is a low-cost technique that also has less of a negative impact on the site than other remediation methods such as excavation. The U.S. EPA broadly defines phytoremediation as "the direct use of living plants for in situ remediation of contaminated soil, sludges, sediments, and ground water through contaminant removal, degradation, or containment."240 Phytoremediation processes potentially include extraction; filtration; stabilization; degradation; and/or evapotranspiration of the contaminant. Additionally, these processes can be mediated by plants and/or plant-associated microorganisms. For example, (1) trichloroethylene (TCE) is taken up and metabolized or transpired by poplar trees; (2) some metals are changed into more bioavailable forms by microorganisms and then taken up by hyperaccumulating plants; and (3) many recalcitrant, organic pollutants are transformed or degraded by plant-associated microorganisms. ${ }^{81,106,116,127,254}$

The rhizosphere, or zone of soil under the influence of plant roots, is well known as a site of elevated microbial numbers and activity. ${ }^{42}$ Additionally, different plant roots select for different rhizosphere populations. ${ }^{115}$ Researchers have recently begun to investigate the potential application of this selectivity for increasing the populations of specific, contaminantremediating, microorganisms in the rhizosphere. .,86 $^{6}$

The selection of specific microorganisms in the rhizosphere has potential advantages for bioaugmentation. ${ }^{117,215}$ Specific rhizosphere-competent microorganisms that degrade a given contaminant can be added to soil along with a plant that supports the growth of these microorganisms. By using the plant-microorganism combination, the microorganism is added to soil along 
with a niche (the plant root) supporting its growth thus increasing the likelihood for the microorganisms' survival. ${ }^{158}$

Siciliano and Germida ${ }^{210}$ have demonstrated the potential of plantmicrobial associations for bioaugmentation of contaminated soil. The researchers inoculated the seed of Dahurian wild rye with Pseudomonas aeruginosa R75 and Pseudomonas savastanoi CB35, which had previously been shown to enhance phytoremediation. ${ }^{208}$ The researchers placed the inoculated seed into soil contaminated with $800 \mu \mathrm{g}$ 3-chlorobenzoate (3-CB)/g. After $28 \mathrm{~d}$ of incubation, the plant-bacterial association in the inoculated planted soil had reduced the 3-CB level to $149 \mu \mathrm{g} 3-\mathrm{CB} / \mathrm{g}$, as compared to 583, 568, and $450 \mu \mathrm{g} 3-\mathrm{CB} / \mathrm{g}$ remaining in the noninoculated control soil, inoculated control soil, and noninoculated planted soil, respectively. The researchers also tested different plant-bacterial combinations with some plants even inhibiting bacterial degradation of $3-\mathrm{CB}$, indicating the need for careful selection of the plant-bacterial combination to be used for remediation. Siciliano and Greer $^{212}$ found similar results for 2,4,6-trinitrotoluene (TNT) degradation by meadow bromegrass inoculated with the TNT-degrader Pseudomonas sp. strain I4.

Likewise, Yee et al. ${ }^{261}$ engineered a recombinant, root-colonizing Pseudomonas fluorescens strain that enhanced TCE remediation. The engineered strain constitutively expressed the enzyme toluene ortho-monooxygenase from Burkholderia cepacia $\mathrm{PR} 1_{23 \mathrm{c}}$. The researchers first isolated a recombinant $P$. fluorescens strain that colonized wheat as well as the wild-type strain, and then used it for subsequent studies. Wheat colonized with the recombinant $P$. fluorescens removed $63 \%$ of the TCE within $4 \mathrm{~d}$ compared to 4,9 , and 13\% removal in sterile soil, noninoculated planted soil, and planted soil inoculated with wild-type $P$. fluorescens, respectively.

Other researchers have investigated the use of fungi for plant-associated bioaugmentation. Meharg and Cairney ${ }^{138}$ reported that 33 out of 42 tested species of ectomycorrhizas (ECM) degraded one or more types of chemicals. Degraded compounds included PCBs and polycyclic aromatic hydrocarbons. ${ }^{57}$ Meharg et al. ${ }^{139}$ demonstrated that the tree Pinus sylvestris mineralized over 3 times as much 2,4-dichlorophenol, within $13 \mathrm{~d}$, when inoculated with the ectomycorrhizae Suillus variegatus as compared to uninoculated trees. Additionally, there is evidence that contaminants including 3-chlorobenzoate are taken-up by mycorrhizal plants and translocated to the plant shoots. ${ }^{54}$ It is unclear if arbuscular mycorrhiza have the same phytoremediation potential as do the ectomycorrhiza. ${ }^{163}$

\section{B. Potential Application of Designer Rhizospheres to Bioaugmentation}

Recent advances in the knowledge of how microorganisms communicate with each other and with plants may enable construction of plants that are 
even more selective for certain microorganisms in the rhizosphere. ${ }^{161,169,194}$ Many different bacteria communicate via chemical signals, including amino acids or short peptides (gram-positive bacteria) and fatty acid derivatives (gram-negative bacteria). ${ }^{253}$ Communication by gram-negative bacteria via $N$-acyl-homoserine lactones (AHL) is one of the most characterized systems. A detailed description of this system is beyond the scope of this review, but briefly, AHL is produced by bacteria at low levels when cell densities are low. When cell numbers increase sufficiently, enough AHL is produced by the community to interact with a transcriptional regulator. The AHL-regulator complex can then bind to target promoter sequences thus initiating gene transcription. ${ }^{132}$ This communication system allows the microorganisms to orchestrate a concerted response to a stimulus. Many different microorganisms also interact either positively or negatively due to cross-communication from the various chemical signals including AHLs. ${ }^{219,253}$ Additionally, it has been shown that some plants produce chemicals that can mimic the bacterial signals. ${ }^{133,229}$

Fray et al. ${ }^{71}$ demonstrated that plants could communicate with bacteria if engineered with AHL genes. The researchers introduced the genes for the AHL $N$-(3-oxohexanoyl)-L-homoserine lactone (OHHL), which enables Erwinia carotovora to infect plants and for the AHL $N$-hexanoylhomoserine lactone (HHL), which contributes to antifungal activity of the biocontrol agent Pseudomonas aureofaciens 30-84 into a tobacco plant. The transgenic plants produced both AHLs. Plant-generated AHLs restored the ability of an OHHLdeficient $E$. carotovora to infect tobacco and partially restored the ability of a HHL-deficient P. aureofaciens 30-84 to inhibit fungal growth. Similarly, Savka and Farrand ${ }^{195}$ used an opine-based system to generate a biased rhizosphere. It has been documented for years that opines play a role in Agrobacteriumplant interactions. ${ }^{16}$ The researchers inoculated a transgenic plant producing an opine with Pseudomonas strains that either could or could not metabolize the opine. The opine-metabolizing strain was preferentially selected in the rhizosphere, achieving a population two to three times that of the non-opine-metabolizing strain. Most of this research on the construction of designer rhizospheres has focused on agricultural applications such as plant protection or plant growth promotion, but there is clearly great potential for the application of this technology to the remediation of contaminated soils with specific plant-microbial combinations. ${ }^{153}$

\section{PHYTOAUGMENTATION}

As mentioned in the phytoremediation section earlier, plants are often used to extract, filter, stabilize, degrade, and/or evapotranspire contaminants. However, the success of these processes often depends on microbial action to modify and/or degrade the contaminant. Since the appropriate 
microorganisms may not be present at a given site and may also be difficult to establish via bioaugmentation, researchers have investigated the insertion of microbial genes for remediation processes directly into plants. ${ }^{18,51,72,78,79,98,207,231}$ Phytoaugmentation is a term used to describe the addition of remediation genes to a site via an engineered plant that contains the microbial genes. By incorporation of these genes into plants, it is also easier to control the persistence and spread of genes introduced into the environment than via an analogous GEM. In fact, several genetically engineered plants, including those engineered with herbicide- or insect-resistance genes, are commonly used in production agriculture. ${ }^{114,168,213}$

The most common approaches for applying this technology to remediation are to incorporate genes for metal binding/transforming proteins, or for organic degradation into the plant. Dhankher et al. ${ }^{51}$ engineered Arabidopsis thaliana with the bacterial genes for arsenate reductase (ars $C$ ) and $\gamma$-glutamylcysteine synthetase $(\gamma$-ECS). Arsenate can potentially be taken up from soil by plants in conjunction with phosphate. ${ }^{140}$ The theory behind the constructed system was that more arsenic could be accumulated by the plant if the arsenate taken up by the plant was reduced to arsenite, which could be sequestered by thiol groups such as $\gamma$-glutamylcysteine. In fact, $A$. thaliana containing the genes for both arsenate reductase and $\gamma$-glutamylcysteine synthetase accumulated two to three times more arsenic than did wild-type plants or the plants engineered with only arsenate reductase or $\gamma$-glutamylcysteine synthetase. Interestingly, the project also demonstrated the need to select the promoter carefully when adding microbial genes to plants. The researchers put the arsenate reductase gene under the control of the soybean rubisco promoter, which is induced by light. The arsenate reductase gene was therefore expressed in above-ground tissues, which allowed the arsenate to be translocated to above-ground portions before it was reduced to arsenite and sequestered. For phytoremediation applications, this would allow the arsenic to be removed from the site by harvesting the above-ground plant material. Similar results have observed by other researchers for methylmercury detoxification and for copper and lead accumulation. ${ }^{18,19,78,231}$

Plants have also been engineered with microbial genes for the metabolism of organic pollutants. Shimizu et al. ${ }^{207}$ introduced the chlorocatechol dioxygenase gene (cbnA) from Ralstonia eutropha NH9 into rice plants. ${ }^{160}$ The gene was cloned under the control of an enhanced cauliflower mosaic virus promoter. Whole calluses of the transgenic rice transformed 3-chlorocatechol to 2-chloromuconate. The chlorocatechol dioxygenase was expressed well in above-ground portions of the plant, but expressed weakly in the roots. Accordingly, 3-chlorocatechol was converted by leaf tissues but not roots. The authors surmised that chlorocatechol dioxygenase activity could have been increased in the roots if they had used a root-specific promoter. Researchers have also engineered plants for the remediation of other organic pollutants including glycerol trinitrate and trinitrotoluene (TNT). ${ }^{72}$ 
Even if the remediation genes are integrated into plants, there is still a risk that the genes may escape to other organisms following environmental release of the transgenic plants. ${ }^{59}$ Kay et al. ${ }^{107}$ demonstrated that transfer of antibiotic resistance genes in transgenic tobacco to Acinetobacter sp. strain BD413 could occur if the transgene contained sequences homologous to those in the Acinetobacter sp. No gene transfer was detected for a transgene without sequences homologous to Acinetobacter sp., but the results also indicated the potential for escape of engineered genes released into the environment.

\section{METHODS FOR ASSESSMENT OF INTRODUCED MICROORGANISMS' SURVIVAL AND ACTIVITY}

Numerous techniques have been developed to monitor the presence and/or activity of microorganisms in environmental samples (Table 3). We next discuss several of these procedures and have categorized them into sections

TABLE 3. Methods for Detecting Survival and Activity of Introduced Microorganisms

\begin{tabular}{|c|c|c|c|}
\hline Method & $\begin{array}{l}\text { Parameter } \\
\text { measured }\end{array}$ & Advantages/disadvantages & Reference \\
\hline 16S rDNA PCR & Presence & $\begin{array}{l}\text { Simple, less expensive than many other } \\
\text { methods. Not quantitative. PCR product } \\
\text { may be further analyzed by other methods, } \\
\text { such as terminal restriction fragment length } \\
\text { polymorphism analysis, to increase } \\
\text { specificity. }\end{array}$ & 129 \\
\hline $\begin{array}{l}\text { Reverse } \\
\text { transcription } \\
\text { PCR }\end{array}$ & Activity & $\begin{array}{l}\text { Determines gene expression. Can be } \\
\text { combined with real-time PCR to be } \\
\text { quantitative. }\end{array}$ & 196 \\
\hline Real-time PCR & $\begin{array}{r}\text { Presence/ } \\
\text { activity }\end{array}$ & $\begin{array}{l}\text { Rapid, quantitative. Very sensitive, possible to } \\
\text { detect }<10^{4} \text { cells/g soil. Can be combined } \\
\text { with reverse transcriptase PCR to measure } \\
\text { gene expression. }\end{array}$ & 182 \\
\hline $\begin{array}{l}\text { Fluorescent in situ } \\
\text { hybridization }\end{array}$ & $\begin{array}{r}\text { Presence/ } \\
\text { activity }\end{array}$ & $\begin{array}{l}\text { Can visualize, enumerate, and identify } \\
\text { microorganisms directly without culturing. } \\
\text { Quantitative. Can analyze complex } \\
\text { communities using multiple probes. }\end{array}$ & 8 \\
\hline Microarrays & $\begin{array}{r}\text { Presence/ } \\
\text { activity }\end{array}$ & $\begin{array}{l}\text { Simultaneous analysis of up to thousands of } \\
\text { genes. Lower sensitivity than other } \\
\text { methods-may require organism to } \\
\text { comprise about } 5 \% \text { of community to be } \\
\text { detected. Can be quantitative. }\end{array}$ & 259 \\
\hline Reporter genes & $\begin{array}{r}\text { Presence/ } \\
\text { activity }\end{array}$ & $\begin{array}{l}\text { Possible to visualize microorganisms in situ. } \\
\text { Quantitative. Luminescent reporters enable } \\
\text { in situ measurement of gene expression. } \\
\text { Multiple different reporters enable } \\
\text { simultaneous study of several organisms. } \\
\text { Requires genetic modification of host. }\end{array}$ & 130 \\
\hline
\end{tabular}


based on their underlying technology instead of their application, since many of the procedures are applicable to both the detection of organisms and monitoring of gene activity.

\section{A. PCR-Based Strategies}

1. 16s rRNA

One of the most commonly used methods for the detection of microorganisms in environmental samples is through PCR amplification of the bacterial small subunit ribosomal RNA gene ${ }^{121}$ (16S rRNA). The 16S rRNA gene is the foundation of bacterial phylogenetic analysis with sequences currently published for thousands of different bacteria. ${ }^{40}$ For bioaugmentation studies, the 16S rRNA gene from the added microorganism(s) can be PCR amplified and detected by gel electrophoresis. ${ }^{91}$ However, if organisms similar to the inoculant are present at the target site, it may be necessary to analyze the $16 \mathrm{~S}$ rRNA PCR product by additional techniques, such as terminal fragment length polymorphism (T-RFLP) analysis or to fully sequence the PCR product, in order to increase the detection specificity. ${ }^{84,91,129,252}$ For example, Lendvay et al. ${ }^{129}$ used $16 \mathrm{~S}$ rRNA PCR in conjunction with T-RFLP analysis to qualitatively assess the survival of a Dehalococcoides-containing inoculum capable of dechlorinating chloroethenes after introduction into a contaminated aquifer. The researchers used primers specific to Dehalococcoides spp. to determine the presence of the inoculant in all samples collected from the bioaugmented treatment within $5 \mathrm{wk}$ of introduction indicating the spread of the inoculant. However, Dehalococcoides spp. were also detected in all of the control samples after $72 \mathrm{~d}$. T-RFLP analysis of a PCR product generated from community DNA with less specific primers confirmed that the inoculant had not spread to the control site and that the detected Dehalococcoides spp. were indigenous populations that developed in response to the biostimulation treatment. Other researchers have used RFLP analysis of 16S rRNA to successfully discriminate between common environmental microorganisms, including Pseudomonas spp. ${ }^{170}$

\section{REVERSE TRANSCRIPTION PCR}

Reverse-transcription PCR (RT-PCR) can be used to monitor microbial gene expression in environmental samples by first converting mRNA to cDNA for further PCR amplification. ${ }^{4,23,120,136,196}$ Bogan et al. ${ }^{23}$ used RT-PCR to quantify (using competitive techniques) the expression of three Phanerochaete chrysosporium manganese peroxidase (MnP) genes during polycyclic aromatic hydrocarbon degradation following bioaugmentation into presterilized soil. High levels of extractable MnP enzyme activity corresponded to high levels of MnP gene RT-PCR transcripts and maximal rates of polycyclic aromatic hydrocarbon degradation. RT-PCR can also be combined with other 
procedures such as fluorescent in situ hybridization and microarray analyses as discussed in subsequent sections. ${ }^{8} 49$ In addition to RT-PCR, researchers have also used techniques such as differential display to assess mRNA levels. ${ }^{69}$ While these studies demonstrate that RT-PCR of environmental microbial genes is possible, it still can be a significant challenge to extract and purify intact mRNA from complex samples, ${ }^{100,205}$ and it may be necessary to optimize the extraction protocol for different samples. ${ }^{100,196,205}$ The sensitivity of RT-PCR may also be an issue due to the labile nature of mRNA.

\section{REAL-TIME PCR}

Real-time quantitative PCR (RTm-PCR) technology has recently been used to rapidly quantify microorganisms following introduction into environmental samples.99,108,129,182,247,255,256 There are various procedures for quantitative and RTm-PCR; ${ }^{186,190}$ however, one of the more specific and widely used techniques is the TaqMan assay. ${ }^{90}$ In the TaqMan procedure for RTm-PCR, the $5^{\prime}$ exonuclease activity of the Taq DNA polymerase digests a fluorogenic TaqMan probe that anneals to an internal DNA site during primer extension. This results in the release of a fluorescent molecule. The cycle threshold (Ct) value is determined at the point where a significant increase in fluorescence emission occurs as compared to the background baseline. A larger initial concentration of DNA template results in a lower $\mathrm{Ct}$ value. Therefore, the DNA template level in a sample can be quantified by comparison with $\mathrm{Ct}$ values obtained from a standard curve of the DNA template. RTm-PCR eliminates the need for gel electrophoresis and allows a sample to be analyzed within hours.

Rodrigues et al. ${ }^{182}$ used RTm-PCR for both the $16 \mathrm{~S}$ rRNA gene and a polychlorinated biphenyl degradative gene to quantify a Rhodococcus sp. after introduction into soil. This system detected $10^{2}$ cells $/ \mathrm{ml}$ in pure culture, but the sensitivity decreased to around $10^{4} \mathrm{cells} / \mathrm{g}$ in soil. Kikuchi et al. ${ }^{108}$ reported RTm-PCR detection based on the soluble methane monooxygenase gene of a trichloroethylene-degrading Methylocystis sp. to be linear over a range of at least $10^{4}$ to $10^{8} \mathrm{cells} / \mathrm{ml}$ in groundwater; however, it was possible to detect as few as $2 \times 10^{2}$ cells $/ \mathrm{ml}$ when suspended in distilled water. Lendvay et al. ${ }^{129}$ indicated that RTm-PCR detection limits for Dehalococcoides spp. and Desulfuromonas spp. in aquifer material were $10^{2}$ and $10^{3}$ cells/g, respectively. It may also be possible to combine RTm-PCR with RT-PCR in order to quantify microbial gene expression in environmental samples..$^{50,198}$

\section{B. Hybridization-Based Strategies}

\section{FLUORESCENT IN SITU HYBRIDIZATION}

Fluorescent in situ hybridization analysis (FISH) is a relatively new technique that can be used to visualize, quantify, and identify environmental microorganisms directly without culturing., $8151,166,179,252,260$ Cells are hybridized 
with a probe that is tagged with a fluorescent molecule thus enabling microscopic detection. Probes are commonly designed based on 16S RNA sequences $^{260}$ but may also be designed for functional genes. ${ }^{8}$ Yang and Zeyer ${ }^{260}$ developed 16S rRNA-targeted FISH probes for Dehalococcoides spp. Two probes were designed to hybridize to 28 different published $16 \mathrm{~S}$ rRNA sequences, primarily from uncultured organisms. One of the probes was demonstrated to hybridize with D. ethenogenes strain 195 and two dehalogenating enrichment cultures, but the other probe was not tested to the unavailability of known cultures that would potentially hybridize to the probe. FISH has also been used to visualize bacteria in biofilms. ${ }^{123}$ Multiple different organisms can be detected using probes attached to various fluorescent molecules. ${ }^{232}$ It is also possible to combine FISH with methods to detect active cells ${ }^{177}$ or mRNA transcripts. ${ }^{8}$ FISH can enable the detection of uncultured microorganisms through hybridization with similar probes, but this can also complicate the monitoring of introduced strains if the probe also binds to indigenous organisms.

\section{MICROARRAYS}

Microarrays are a powerful tool to simultaneously assess the presence or activity of up to thousands of different genes. ${ }^{22,38,49,259,263,264}$ This could be useful when bioaugmenting with a culture containing multiple organisms or for detecting several genes such as in a degradation pathway. Microarrays can also be quantitative. ${ }^{38}$ In environmental analysis, microarrays have typically been used to detect the presence of different $16 \mathrm{~S}$ rRNA or functional genes from indigenous organisms; $;^{22,259,263}$ however, microarrays can also be used to monitor the survival and activity of an inoculant. Dennis et al. ${ }^{49}$ used RT-PCR and microarray technology to monitor Ralstonia eutropha JMP134 gene expression during 2,4-dichlorophenoxyacetic acid (2,4-D) degradation in a mixed culture. Induction of five different 2,4-D genes was measured by first converting the genes to CDNA, using RT-PCR for subsequent microarray analysis. Activity of four of the genes was detected from $10^{6}$ cells $/ \mathrm{ml}$ or fewer against a background of $10^{8}$ cells $/ \mathrm{ml}$. Significant induction of the other gene was not detected due to high variability. Despite the potential advantage of analyzing multiple genes, microarrays can be difficult to use with environmental samples due to the technique's low detection sensitivity. Cho and Tiedje $^{38}$ estimated that an organism containing a target DNA sequence would need to comprise $5 \%$ of the total DNA in the sample in order to be detectable by microarray technology; however, this can be improved somewhat through alterations in the hybridization methodology such as increasing the amount of environmental DNA used for analysis.

\section{USE OF REPORTER GENES}

One major advance that was enabled by genetic engineering is the development of reporter genes. The use of reporter genes for environmental research 
has increased greatly in recent years as evidenced by several recent reviews discussing the topic. ${ }^{112,130,145,187,196}$ For bioaugmentation specifically, reporter genes can allow for more sensitive monitoring of the presence and activity of introduced microorganisms. Several different reporter genes have been developed, ${ }^{112,220}$ but the bacterial luciferase ( $u x$ ) and jellyfish green fluorescent protein $(g f p)$ genes are currently the most widely used for environmental applications. Both the $l u x$ and gfp genes can emit signals without addition of an external substrate-in contrast to many early reporter genes that required addition of an exogenous substrate for detection. Expression of the $l u x$ genes results in light emission, while expression of the gfp gene produces a fluorescent protein (GFP). A major distinction between the potential applications for the two reporters is due to their persistence once expressed. Luminescence from the lux genes is short-lived, making it suitable for real-time detection of gene expression, while fluorescence from GFP persists longer, making it more applicable to the detection of cumulative gene expression or the presence of whole microorganisms. ${ }^{32}$

Microorganisms containing $l u x$ and/or gfp have been added to contaminated soils for the purposes of remediation or assessment of contaminant bioavailability. In the first field release in the United States of a genetically engineered microorganism for bioremediation, Ripp et al. ${ }^{180}$ added Pseudomonas fluorescens HK44, containing lux genes fused with the naphthalene degradative pathway, into soil contaminated with naphthalene, anthracene, and phenanthrene. The engineered microorganism successfully provided real-time data on naphthalene bioavailability and degradation based on luminescence as detected by fiber optic/photon multiplier tube techniques. Additionally, over $10^{2}$ CFU of $P$. fluorescens HK44/g soil remained even after $660 \mathrm{~d}$ of incubation, indicating the potential for long-term survival of GEMs after release into the environment.

Historically, $g f p$ has often been used to detect the survival of GEMs added to soil or water. ${ }^{10,43}$ The GFP-containing cells can be detected by epifluorescence microscopy or by visualization of cultured bacteria on plates with long-wave ultraviolet (UV) or black light. ${ }^{10,237}$ The $g f p$-tagged cells can also be used to detect gene expression. ${ }^{34,96}$ The $g f p$ gene has found particular use in dual-labeling applications with other reporter genes. By using dual labels, it is possible to concurrently measure (1) survival and activity of an introduced organism, or (2) dynamics of multiple different introduced organisms. Unge et al. ${ }^{237}$ integrated $g f p$ and $l u x A B$ genes under the control of a strong constitutive promoter into the chromosome of Pseudomonas fluorescens SBW25. Expression of luminescence varied with metabolic activity of the cells, since it required reducing equivalents to be activated, while production of GFP was independent of the cells' metabolic status. The authors were able to determine that tagged cells survived at high levels when added to soil, but the cells' metabolic activity decreased as nutrients became limiting. Elväng et al. ${ }^{66}$ found similar results by incorporating the GFP ( $g f p$ ) or firefly 
luciferase ( $l u c$ ) genes into the chromosome of the 4-chlorophenol degrader Arthrobacter chlorophenolicus A6. A culture containing both luc-tagged $A$. chlorophenolicus A6 and gfp-tagged A. chlorophenolicus A6 was added to 4-chlorophenol contaminated soil. The authors were unable to get both $g f p$ and $l u c$ to be expressed in A. chlorophenolicus A6 containing both of the genes, in contrast to the results for P. fluorescens SBW25. ${ }^{237}$ Bloemberg et al. ${ }^{20}$ were able to visualize the dynamics of up to three different populations of $P$. fluorescens in the rhizosphere by using different reporter genes. The researchers added mixed cultures of $P$. fluorescens, each containing genes for one of four different fluorescent proteins, to the rhizosphere. The bacterial community dynamics were monitored with confocal laser scanning microscopy.

Reporter genes can be instrumental in bioaugmentation research and even in real-world applications as evidenced by research detailed above. However, care should be taken when conducting experiments using reporter genes and also during data interpretation. Reporter genes on mobile genetic elements such as plasmids may be transferred to indigenous organisms which could lead to erroneous results. Additionally, even small fluctuations in environmental conditions can exert a large impact on the activity of some reporter genes. ${ }^{154}$ For example, Dorn et al. ${ }^{58}$ found that variations as low as a $1^{\circ} \mathrm{C}$ change in temperature, 0.2 units change in $\mathrm{pH}$, or 1 order of magnitude change in initial cell number could alter $u x$ expression by Pseudomonas putida RB1353 during metabolism of salicylate and naphthalene. The authors concluded that their research confirmed the potential of $l u x$-based systems for controlled laboratory experiments, but that interpretation of $l u x$ data from complex field environments would be difficult. Leveau and Lindow ${ }^{130}$ had similar conclusions regarding interpretation of reporter gene data and stated, "in microbial ecology, this responsibility [determining what the data truly indicates] lies not with the bioreporter but with the microbial ecologist, whose greatest challenge is to translate bioreporter data into a meaningful account of the microbe's biology and its perception of the world" (p. 263).

\section{BIOAUGMENTATION IMPACT ON INDIGENOUS MICROORGANISMS}

Since the primary focus of bioaugmentation is to enhance contaminant remediation, the resulting impact of bioaugmentation on indigenous microbial populations is often overlooked. While the impact of bioaugmentation on microbial communities in contaminated sites is probably secondary to that imposed by the presence of the contaminant, it is worthwhile to consider these bioaugmentation effects especially when using genetically modified organisms. 
Addition of intact microorganisms to soil can potentially result in establishment of new microbial populations, shifts in microbial populations, and/or transfer of genetic material to indigenous microorganisms. Jernberg and Jansson ${ }^{102}$ investigated the impact that 4-chlorophenol contamination and/or inoculation with the 4-chlorophenol-degrader Arthrobacter chlorophenolicus A6L had on the structure of the soil bacterial community. The authors used T-RFLP analysis to generate fingerprints of the bacterial communities. Some populations increased following addition of A. chlorophenolicus A6L or 4-chlorophenol, and some populations decreased. It is difficult to determine whether addition of the inoculant only, or the contaminant only, had the greater impact, since 25 and 27 T-RFLPs were significantly changed in the respective treatments relative to the control soil. When the inoculant and contaminant were added together, 41 T-RFLPs were significantly changed. Most of the populations reacted to the combined addition in a similar manner to that of the individual addition of the inoculant or contaminant, but some reacted differently, indicating a greater impact by either the inoculant or contaminant. Other researchers have found that addition of an inoculant can reduce the negative impact a contaminant has on indigenous microbial populations. ${ }^{25,77}$ Inoculation of plant roots can also impact rhizosphere community diversity, but the effect is probably less than that of the plant species and soil used. ${ }^{142,202,209}$

Genes can be transferred from introduced organisms to indigenous microorganisms even when that is not the original goal. Thiem et al. ${ }^{230}$ added the 3-chlorobenzoate (3-CB) degrader Pseudomonas sp. B13 to an aquifer. Over 14 mo later, the researchers isolated a novel 3-CB-degrading bacterium from the site. It was later confirmed that the 3-CB-degrading genes in the novel bacterium were identical to those in the Pseudomonas sp. B13 inoculant, but the method by which the genes were transferred was not determined. ${ }^{265}$ A genetically modified Sinorbizobium meliloti was found to survive in soil at least $6 \mathrm{yr}$ after a field release, and transfer of its plasmid to other bacteria was detected even though the plasmid was not selftransmissible. ${ }^{148}$ These results indicate the risk for escape of engineered genes to indigenous microorganisms if appropriate cautions are not taken.

Even if engineered microbial genes are incorporated into plants in order to reduce the risk for their escape, addition of the genes to the site via phytoaugmentation can alter the soil microbial community. James Germida's lab has conducted extensive field tests on genetically engineered canola. ${ }^{61,143,211}$ The rhizosphere and root interior microbial communities were different for a cultivar engineered with glyphosate resistance genes compared to the cultivar from which it was derived, based on fatty acid methyl ester and communitylevel physiological profiles. The authors hypothesized that the differences may have been due to altered root exudation patterns in the engineered plant. 
The research indicates that bioaugmentation with a microbial culture can affect the composition of the indigenous microbial community. However, it is uncertain if the effects are long-term or just short-lived. Additionally, whether the changes are positive or negative may depend on the individual microorganism affected. The greater risk is probably from escape of engineered genes to indigenous microorganisms, with unforeseeable results.

\section{FIELD-SCALE BIOAUGMENTATION STUDIES}

\section{A. Soil Bioaugmentation}

The majority of bioaugmentation research, including most of what we have discussed thus far in this review, has occurred as laboratory-scale experiments using small quantities of soil (often $<1 \mathrm{~kg}$ ). It is more difficult to conduct bioaugmentation research in the field due to spatial heterogeneity in the soil along with the variability of contaminant concentrations throughout the site. One method researchers have used to better simulate actual field conditions is to conduct "intermediate field scale" experiments $94,118,119,155,181,223$ (Table 4). For this method, researchers use large quantities (many kilograms) of soil and conduct the experiment under actual field conditions-fluctuating temperature, etc. The soil is typically excavated and/or mixed prior to the beginning of the experiment thus reducing the heterogeneity between different samples. For instance, Lamar et al. ${ }^{118}$ excavated $183 \mathrm{~m}^{3}$ of PCP- and creosote-contaminated soil from a pole-treatment facility. The soil was passed through an $8-\mathrm{cm}$ screen and then split into $5-\mathrm{m}^{3}$ piles. If necessary, the soil was mixed with clean soil to achieve a target PCP concentration of $700 \mathrm{mg} / \mathrm{kg}$. Selected plots were then bioaugmented with the fungus Phanerochaete sordida. After $20 \mathrm{wk}$, significantly less of the original PCP was recovered in the bioaugmented soil (36\%) as compared to the control soil (82\%). The authors also found that bioaugmentation tended to increase the degradation of four-ring polycyclic aromatic hydrocarbons (PAHs), but tended to inhibit the degradation of three-ring PAHs.

\section{B. Aquifer Bioaugmentation}

One area in which bioaugmentation has found both research and commercial success is the remediation of contaminated aquifers $^{27,45,60,63-65,89,103,129,191,218,258}$ (Table 4). Specifically, sites contaminated with chlorinated ethenes, including trichloroethene (TCE) and tetrachloroethene (PCE), have received considerable attention due their widespread occurrence as groundwater contaminants. ${ }^{65,129,135,218}$ Indigenous microorganisms at these contaminated sites are often only capable of reducing TCE or PCE to dichloroethene (DCE) instead of completely 


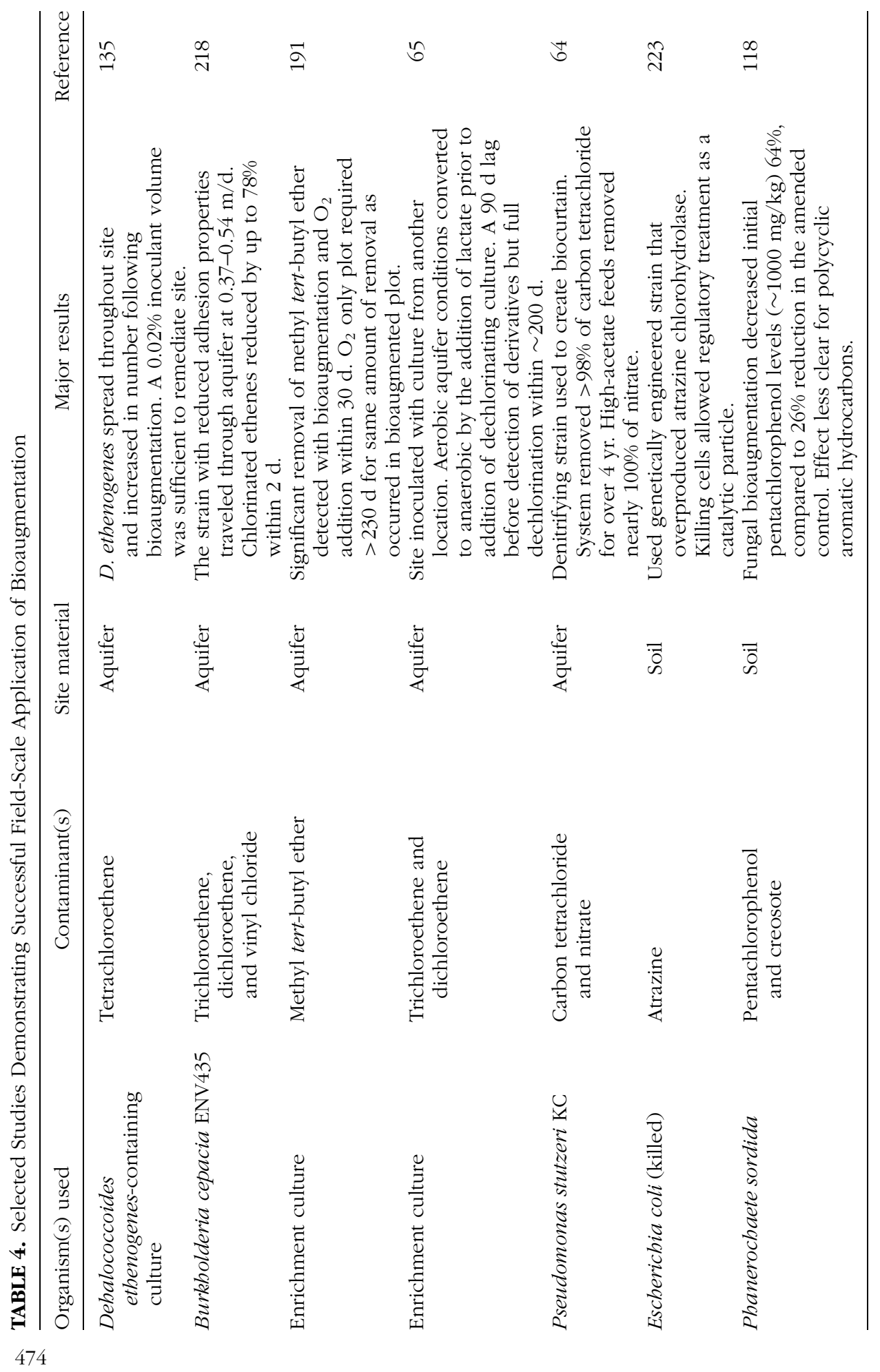


dechlorinating them to ethene..$^{91}$ Only Dehalococcoides ethenogenes strain 195 and related organisms are known to be capable of completely dechlorinating TCE and PCE through use as a terminal electron acceptor, ${ }^{91}$ although other organisms are capable of transforming or degrading chlorinated ethenes via different pathways. ${ }^{218}$ Several studies have investigated the bioaugmentation of contaminated sites with enrichment cultures containing D. ethenogenes or similar organisms, ${ }^{65,129,135}$ and some of these cultures are commercially available (Bioremediation Consulting, Inc., Watertown, MA; Site Recovery \& Management, Guelph, Ontario, Canada). Lendvay et al. ${ }^{129}$ compared the ability of biostimulation and bioaugmentation with a Dehalococcoides-containing dechlorinating inoculum to remediate an aquifer contaminated with chloroethenes. Lactate was added as the electron donor. Within $43 \mathrm{~d}$ of bioaugmentation, $92 \%$ of the aqueous chlorinated ethenes were converted to ethene, in contrast to only $76 \%$ being converted to ethene after $121 \mathrm{~d}$ in biostimulation plots. The total aqueous concentration of chlorinated ethenes in the control plot was largely unchanged during the experiment. The researchers used Dehalococcoides-specific PCR to monitor spread of the inoculant throughout the site and RTm-PCR to quantify a three to four orders of magnitude increase in population. There was also an increase in Debalococcoides spp. numbers in the biostimulation plot, although more gradual than in the bioaugmentation plot, immediately prior to rapid dechlorination activity, but T-RFLP analysis was used to confirm that these were indigenous organisms and that they had not spread from the bioaugmented site.

The research on aquifers contaminated with chlorinated ethenes illustrates that traditional techniques such as cell bioaugmentation can be effectively used to remediate a site if the inoculant can fill a niche in the environmental ecosystem ${ }^{21}$-in this case, the use of the chlorinated ethenes as a terminal electron acceptor. However, the vast majority of the field-scale bioaugmentation experiments have only investigated the cell bioaugmentation approach. Since traditional bioaugmentation techniques may not work at all sites, additional research is needed at the field-scale level on alternative bioaugmentation methods such as gene bioaugmentation or the use of GEMs. ${ }^{155,223,246}$

\section{CONCLUSIONS}

There have been many advances in bioaugmentation research over the last few years that may ultimately translate into the enhanced remediation of pollutants at contaminated field sites. Cell bioaugmentation remains the most commonly used technique for adding a microbial inoculant to a contaminated site, but alternative methods such as the use of immobilized microorganisms or activated soil may increase the success rate of this approach. Additionally, 
several other bioaugmentation approaches, including gene bioaugmentation, rhizosphere bioaugmentation, and phytoaugmentation, are currently in the developmental stages, and may greatly broaden the range of applications for the bioaugmentation-based remediation of contaminated sites. Microorganisms or plants that have been genetically altered to increase their remediation potential may also be applicable to bioaugmentation. Overall, these new bioaugmentation approaches appear to have great potential for contaminant remediation, but continued research is needed, especially at the field-scale level, in order to test and refine the developing technologies before widespread application on a commercial basis. Furthermore, given the unknown risks resulting from the inevitable transfer of genes from introduced genetically engineered microorganisms to environmental organisms, it is advisable to use a proven bioaugmentation method with a nonengineered strain, provided it is suitable to the specific target site.

\section{ACKNOWLEDGMENTS}

We thank Liza F. Gentry for assistance with the preparation of this manuscript. This work was supported by NIEHS Basic Superfund grant 5 P42 ESO4940-09.

\section{REFERENCES}

1. Aggarwal, N., HogenEsch, H., Guo, P., North, A., Suckow, M., Mittal, S.K. Biodegradable alginate microspheres as a delivery system for naked DNA, Can. J. Vet. Res. 63, 148, 1999.

2. Ahrenholtz, I., Lorenz, M.G., and Wackernagel, W. A conditional suicide system in Escherichia coli based on the intracellular degradation of DNA, Appl. Environ. Microbiol. 60, 3746, 1994.

3. Alexander, M. Biodegradation and bioremediation, 2nd ed., p. 453. Academic Press, San Diego, CA, 1999.

4. Alfreider, A., Vogt, C., and Babel, W. Expression of chlorocatechol 1,2dioxygenase and chlorocatechol 2,3-dioxygenase genes in chlorobenzenecontaminated subsurface samples, Appl. Environ. Microbiol. 69, 1372, 2003.

5. Amarger, N. Genetically modified bacteria in agriculture, Biochimie, 84, 1061, 2002.

6. Anderson, T.A., Guthrie, E.A., and Walton, B.T. Bioremediation in the rhizosphere, Environ. Sci. Technol. 27, 2630, 1993.

7. Atlas, R.M. Molecular methods for environmental monitoring and containment of genetically engineered microorganisms, Biodegradation 3, 137, 1992.

8. Bakermans, C., and Madsen, E.L. Detection in coal tar waste-contaminated groundwater of mRNA transcripts related to naphthalene dioxygenase by fluorescent in situ hybridization with tyramide signal amplification, J. Microbiol. Methods 50, 75, 2002. 
9. Barbeau, C., Deschênes, L., Karamanev, D., Comeau, Y., and Samson, R. Bioremediation of pentachlorophenol-contaminated soil by bioaugmentation using activated soil, Appl. Microbiol. Biotechnol. 48, 745, 1997.

10. Bastos, A.E.R., Cassidy, M.B., Trevors, J.T., Lee, H., and Rossi, A. Introduction of green fluorescent protein gene into phenol-degrading Alcaligenes faecalis cells and their monitoring in phenol-contaminated soil, Appl. Microbiol. Biotechnol. 56, 255, 2001.

11. Beck, D.P. Suitability of charcoal-amended mineral soil as carrier for Rhizobium inoculants, Soil Biol. Biochem. 23, 41, 1991.

12. Bej, A.K., Perlin, M.H., and Atlas, R.M. Model suicide vector for containment of genetically engineered microorganisms, Appl. Environ. Microbiol. 54, 2472, 1988.

13. Ben Rebah, F., Tyagi, R.D., and Prevost, D. Wastewater sludge as a substrate for growth and carrier for rhizobia: The effect of storage conditions on survival of Sinorbizobium meliloti, Bioresour. Technol. 83, 145, 2002.

14. Bennett, J.W. Mycotechnology: The role of fungi in biotechnology, J. Biotechnol. 66, 101, 1998.

15. Bent, E., Tuzun, S., Chanway, C.P., and Enebak, S. Alterations in plant growth and in root hormone levels of lodgepole pines inoculated with rhizobacteria, Can. J. Microbiol. 47, 793, 2001.

16. Bevan, M.W., and Chilton, M.D. T-DNA of the Agrobacterium Ti and Ri plasmids, Annu. Rev. Genet. 16, 357, 1982.

17. Bhandari, A., and Xu, F. Impact of peroxidase addition on the sorptiondesorption behavior of phenolic contaminants in surface soils, Environ. Sci. Technol. 35, 3163, 2001.

18. Bizily, S.P., Rugh, C.L., and Meagher, R.B. Phytodetoxification of hazardous organomercurials by genetically engineered plants, Nat. Biotechnol. 18, 213, 2000 .

19. Bizily, S.P., Rugh, C.L., Summers, A.O., and Meagher, R.B. Phytoremediation of methylmercury pollution: merB expression in Arabidopsis thaliana confers resistance to organomercurials, Proc. Natl. Acad. Sci. USA 96, 6808, 1999.

20. Bloemberg, G.V., Wijfjes, A.H.M., Lamers, G.E.M., Stuurman, N., and Lugtenberg, B.J.J. Simultaneous imaging of Pseudomonas fluorescens WCS365 populations expressing three different autofluorescent proteins in the rhizosphere: New perspectives for studying microbial communities, Mol. Plant Microbe Interact. 13, 1170, 2000.

21. Blumenroth, P., and Wagner-Döbler, I. Survival of inoculants in polluted sediments: Effect of strain origin and carbon source competition, Microb. Ecol. 35, 279, 1998.

22. Bodrossy, L., Stralis-Pavese, N., Murrell, J.C., Radajewski, S., Weilharter, A., and Sessitsch, A. Development and validation of a diagnostic microbial microarray for methanotrophs, Environ. Microbiol. 5, 566, 2003.

23. Bogan, B.W., Schoenike, B., Lamar, R.T., and Cullen, D. Manganese peroxidase mRNA and enzyme activity levels during bioremediation of polycyclic aromatic hydrocarbon-contaminated soil with Phanerochaete chrysosporium, Appl. Environ. Microbiol. 62, 2381, 1996. 
24. Boon, N., De Gelder, L., Lievens, H., Siciliano, S.D., Top, E.M., and Verstraete, W. Bioaugmenting bioreactors for the continuous removal of 3-chloroaniline by a slow release approach, Environ. Sci. Technol. 36, 4698, 2002.

25. Boon, N., Top, E.M., Verstraete, W., and Siciliano, S.D. Bioaugmentation as a tool to protect the structure and function of an activated-sludge microbial community against a 3-chloroaniline shock load, Appl. Environ. Microbiol. 69, 1511, 2003.

26. Bouchez, T., Patureau, D., Dabert, P., Juretschko, S., Dore, J., Delgenes, P., Moletta, R., and Wagner, M. Ecological study of a bioaugmentation failure, Environ. Microbiol. 2, 179, 2000.

27. Bourquin, A.W., Mosteller, D.C., Olsen, R.L., Smith, M.J., and Reardon, K.F. Aerobic bioremediation of TCE-contaminated groundwater: Bioaugmentation with Burkholderia cepacia PR1 $1_{301}$, in In situ and on-site bioremediation, vol. 4, pp. 513-518, Batelle Press, Columbus, OH, 1997.

28. Briglia, M., Nurmiaho-Lassila, E.-L., Vallini, G., and Salkinoja-Salonen, M. The survival of the pentachlorophenol-degrading Rhodococcus chlorophenolicus PCP-1 and Flavobacterium sp. in natural soil, Biodegradation 1, 273, 1990.

29. Brown, D.G., and Jaffé, P.R. Effects of nonionic surfactants on bacterial transport through porous media, Environ. Sci. Technol. 35, 3877, 2001.

30. Bruhlmann, F., and Chen, W. Tuning biphenyl dioxygenase for extended substrate specificity, Biotechnol. Bioeng. 63, 544, 1999.

31. Burchhardt, G., Schmidt, I., Cuypers, H., Petruschka, L., Volker, A., and Herrmann, H. Studies on spontaneous promoter-up mutations in the transcriptional activator-encoding gene $p h I R$ and their effects on the degradation of phenol in Escherichia coli and Pseudomonas putida, Mol. Gen. Genet. 254, 539, 1997.

32. Burlage, R.S. Emerging technologies: Bioreporters, biosensors, and microprobes, In Manual of environmental microbiology, ed. C.J. Hurst, pp. 115-123. ASM, Washington, DC, 1997.

33. Caccavo, F., Jr., Ramsing, N.B., and Costerton, J.W. Morphological and metabolic responses to starvation by the dissimilatory metal-reducing bacterium Shewanella alga BrY, Appl. Environ. Microbiol. 62, 4678, 1996.

34. Casavant, N.C., Thompson, D., Beattie, G.A., Phillips, G.J., and Halverson, L.J. Use of a site-specific recombination-based biosensor for detecting bioavailable toluene and related compounds on roots, Environ. Microbiol. 5, 238, 2003.

35. Caspi, R., Pacek, M., Consiglieri, G., Helinski, D.R., Toukdarian, A., and Konieczny, I. A broad host range replicon with different requirements for replication initiation in three bacterial species, EMBO J. 20, 3262, 2001.

36. Cassidy M.B., Lee, H., and Trevors, J.T. Environmental applications of immobilized microbial cells: A review, J. Ind. Microbiol. 16, 79, 1996.

37. Cebolla, A., Sousa, C., and de Lorenzo, V. Rational design of a bacterial transcriptional cascade for amplifying gene expression capacity, Nucleic Acids Res. 29, 759, 2001.

38. Cho, J.-C., and Tiedje, J.M. Quantitative detection of microbial genes by using DNA microarrays, Appl. Environ. Microbiol. 68, 1425, 2002. 
39. Christensen, B.B., Sternberg, C., Andersen, J.B., Eberl, L., Møller, S., Givskov, M., and Molin, S. Establishment of new genetic traits in a microbial biofilm community, Appl. Environ. Microbiol. 64, 2247, 1998.

40. Cole, J.R., Chai, B., Marsh, T.L., Farris, R.J., Wang, Q., Kulam, S.A., Chandra, S., McGarrell, D.M., Schmidt, T.M., Garrity, G.M., and Tiedje, J.M. The ribosomal Database Project (RDP-II): Previewing a new autoaligner that allows regular updates and the new prokaryotic taxonomy, Nucleic Acids Res. 31, 442, 2003.

41. Contreras, A., Molin, S., and Ramos, J.-L. Conditional-suicide containment system for bacteria which mineralize aromatics, Appl. Environ. Microbiol. 57, 1504, 1991.

42. Curl, E.A., and Truelove, B. The Rhizosphere, Springer-Verlag, Berlin, 1986, 288.

43. Dandie, C.E., Thomas, S.M., and McClure, N.C. Comparison of a range of green fluorescent protein-tagging vectors for monitoring a microbial inoculant in soil, Lett. Appl. Microbiol. 32, 26, 2001.

44. de Lorenzo, V., Herrero, M., Jakubzik, U., and Timmis, K.N. Mini-Tn5 transposon derivatives for insertion mutagenesis, promoter probing, and chromosomal insertion of cloned DNA in Gram-negative eubacteria, J. Bacteriol. 172, 6568, 1990.

45. De Wildeman, S., Linthout, G., Van Langenhove, H., and Verstraete, W. Complete lab-scale detoxification of groundwater containing 1,2-dichloroethane, Appl. Microbiol. Biotechnol. 63, 609, 2004.

46. Dean, S.M., Jin, Y., Cha, D.K., Wilson, S.V., and Radosevich, M. Phenanthrene degradation in soils co-inoculated with phenanthrene-degrading and biosurfactant-producing bacteria, J. Environ. Qual. 30, 1126, 2001.

47. Dejonghe, W., Boon, N., Seghers, D., Top, E.M., and Verstraete, W. Bioaugmentation of soils by increasing microbial richness: Missing links, Environ. Microbiol. 3, 649, 2001.

48. Dejonghe, W., Goris, J., El Fantroussi, S., Höfte, M., De Vos, P., Verstraete, W., and Top, E.M. Effect of dissemination of 2,4-dichlorophenoxyacetic acid (2,4D) degradation plasmids on 2,4-D degradation and on bacterial community structure in two different soil horizons, Appl. Environ. Microbiol. 66, 3297, 2000.

49. Dennis, P., Edwards, E.A., Liss, S.N., and Fulthorpe, R. Monitoring gene expression in mixed microbial communities by using DNA microarrays, Appl. Environ. Microbiol. 69, 769, 2003.

50. Devers, M., Soulas, G., and Martin-Laurent, F. Real-time reverse transcription PCR analysis of expression of atrazine catabolism genes in two bacterial strains isolated from soil, J. Microbiol. Methods 56, 3, 2004.

51. Dhankher, O.P., Li, Y., Rosen, B.P., Shi, J., Salt, D., Senecoff, J.F., Sashti, N.A., and Meagher, R.B. Engineering tolerance and hyperaccumulation of arsenic in plants by combining arsenate reductase and $\gamma$-glutamylcysteine synthetase expression, Nat. Biotechnol. 20, 1140, 2002.

52. Diaz, E., Munthali, M., de Lorenzo, V., and Timmis, K.N. Universal barrier to lateral spread of specific genes among microorganisms, Mol. Microbiol. 13, 855, 1994. 
53. DiGiovanni, G.D., Neilson, J.W., Pepper, I.L., and Sinclair, N.A. Gene transfer of Alcaligenes eutrophus JMP134 plasmid pJP4 to indigenous soil recipients, Appl. Environ. Microbiol. 62, 2521, 1996.

54. Dittmann, J., Heyser, W., and Bucking, H. Biodegradation of aromatic compounds by white rot and ectomycorrhizal fungal species and the accumulation of chlorinated benzoic acid in ectomycorrhizal pine seedlings, Chemosphere 49, 297, 2002.

55. Dong, H., Onstott, T.C., Deflaun, M.F., Fuller, M.E., Scheibe, T.D., Streger, S.H., Rothmel, R.K., and Mailloux, B.J. Relative dominance of physical versus chemical effects on the transport of adhesion-deficient bacteria in intact cores from South Oyster, Virgina, Environ. Sci. Technol. 36, 891, 2002.

56. Dong, Q., Springeal, D., Schoeters, J., Nuyts, G., Mergeay, M., and Diels, L. Horizontal transfer of bacterial heavy metal resistance genes and its applications to activated sludge systems, Water Sci. Tech. 37, 465, 1998.

57. Donnelly, P.K., Fletcher, J.S. Potential use of mycorrhizal fungi as bioremediation agents, In Bioremediation through rhizosphere technology, eds. T.A. Anderson and J.R. Coats, pp. 93-99. American Chemical Society, Washington, DC, 1994.

58. Dorn, J.G., Frye, R.J., and Maier, R.M. Effect of temperature, pH, and initial cell number on luxCDABE and nab gene expression during naphthalene and salicylate catabolism in the bioreporter organism Pseudomonas putida RB1353, Appl. Environ. Microbiol. 69, 2209, 2003.

59. Dröge, M., Pühler, A., and Selbitschka, W. Horizontal gene transfer as a biosafety issue: A natural phenomenon of public concern, J. Biotechnol. 64, 75, 1998.

60. Duba, A.G., Jackson, K.J., Jovanovich, M.C., Knapp, R.B., and Taylor, R.T. TCE remediation using in situ, resting-state bioaugmentation, Environ. Sci. Technol. 30, 1982, 1996.

61. Dunfield, K.E., and Germida, J.J. Diversity of bacterial communities in the rhizosphere and root interior of field-grown genetically modified Brassica napus, FEMS Microbiol. Ecol. 38, 1, 2001.

62. Duquenne, P., Chenu, C., Richard, G., and Catroux, G. Effect of carbon source supply and its location on competition between inoculated and established bacterial strains in sterile soil microcosm, FEMS Microbiol. Ecol. 29, 331, 1999.

63. Dybas, M.J., Bezborodinikov, S., Voice, T., Wiggert, D.C., Davies, S., Tiedje, J., Criddle, C.S., Kawka, O., Barcelona, M., and Mayotte, T. Evaluation of bioaugmentation to remediate an aquifer contaminated with carbon tetrachloride, in In situ and on-site bioremediation, vol. 4, pp. 507-512. Batelle Press, Columbus, OH, 1997.

64. Dybas, M.J., Hyndman, D.W., Heine, R., Tiedje, J., Linning, K., Wiggert, D., Voice, T., Zhao, X., Dybas, L., and Criddle, C.S. Development, operation, and long-term performance of a full-scale biocurtain utilizing bioaugmentation, Environ. Sci. Technol. 36, 3635, 2002.

65. Ellis, D.E., Lutz, E.J., Odom, J.M., Buchanan, R.J., Jr., Bartlett, C.L., Lee, M.D., Harkness, M.R., and Deweerd, K.A. Bioaugmentation for accelerated in situ anaerobic bioremediation, Environ. Sci. Technol. 34, 2254, 2000.

66. Elväng, A.M., Westerberg, K., Jernberg, C., and Jansson, J.K. Use of green fluorescent protein and luciferase biomarkers to monitor survival and activity of 
Arthrobacter chlorophenolicus A6 cells during degradation of 4-chlorophenol in soil, Environ. Microbiol. 3, 32, 2001.

67. European Parliament and The Council of the European Community, Directive 2001/18/EC [Online], available at http://europa.eu.int/eur-lex/pri/en/ oj/dat/2001/1_106/1_10620010417en00010038.pdf, 2001 (verified 14 February 2004).

68. Fang, M., and Wong, J.W. Seeding effect on cocomposting wastewater biosolids with coal ash, Water Environ. Res. 73, 633, 2001.

69. Fleming, J.T., Yao, W.H., and Sayler, G.S. Optimization of differential display of prokaryotic mRNA: Application to pure culture and soil microcosms, Appl. Environ. Microbiol. 64, 3698, 1998.

70. Ford, C.Z., Sayler, G.S., and Burlage, R.S. Containment of a genetically engineered microorganism during a field bioremediation application, Appl. Microbiol. Biotechnol. 51, 397, 1999.

71. Fray, R.G., Throup, J.P., Daykin, M., Wallace, A., Williams, P., Stewart, G.S.A.B., and Grierson, D. Plants genetically modified to produce $\mathrm{N}$ acylhomoserine lactones communicate with bacteria, Nat. Biotechnol. 17, 1017, 1999.

72. French, C.E., Rosser, S.J., Davies, G.J., Nicklin, S., and Bruce, N.C. Biodegradation of explosives by transgenic plants expressing pentaerythritol tetranitrate reductase, Nat. Biotechnol. 17, 491, 1999.

73. Ganguli, A., and Tripathi, A.K. Bioremediation of toxic chromium from electroporating effluent by chromate-reducing Pseudomonas aeruginosa A2Chr in two bioreactors, Appl. Microbiol. Biotechnol. 58, 416, 2002.

74. Garcia-Junco, M., Gomez-Lahoz, C., Niqui-Arroyo, J.L.. and Ortega-Calvo, J.J. Biosurfactant- and biodegradation-enhanced partitioning of polycyclic aromatic hydrocarbons from nonaqueous-phase liquids, Environ. Sci. Technol. 37, 2988, 2003.

75. Gardin, H., and Pauss, A. $\kappa$-Carrageenan/gelatin gel beads for the coimmobilization of aerobic and anaerobic microbial communities degrading 2,4,6-trichlorophenol under air-limited conditions, Appl. Microbiol. Biotechnol. 56, 517, 2001.

76. Gentry, T.J., Josephson, K.L., and Pepper, I.L. Functional establishment of introduced chlorobenzoate degraders following bioaugmentation with newly activated soil, Biodegradation 15, 67, 2004.

77. Gentry, T.J., Newby, D.T., Josephson, K.L., and Pepper, I.L. Soil microbial population dynamics following bioaugmentation with a 3-chlorobenzoatedegradaing bacterial culture, Biodegradation 12, 349, 2001.

78. Gisbert, C., Ros, R., De Haro, A., Walker, D.J., Pilar Bernal, M., Serrano, R., and Navarro-Avino, J. A plant genetically modified that accumulates $\mathrm{Pb}$ is especially promising for phytoremediation, Biochem. Biophys. Res. Commun. 303, 440, 2003.

79. Gleba, D., Borisjuk, N.V., Borisjuk, L.G., Kneer, R., Poulev, A., Skarzhinskaya, M., Dushenkov, S., Logendra, S., Gleba, Y.Y., and Raskin, I. Use of plant roots for phytoremediation and molecular farming, Proc. Natl. Acad. Sci. USA 96, 5973, 1999. 
80. Glick, B.R., and Pasternak, J.J. Molecular Biotechnology-Principles and Applications of Recombinant DNA, 2nd ed., p. 683. ASM Press, Washington, DC, 1998.

81. Gordon, M., Choe, N., Duffy, J., Ekuan, G., Heilman, P., Muiznieks, I., Ruszaj, M., Shurtleff, B.B., Strand, S., Wilmoth, J., and Newman, L.A. Phytoremediation of trichloroethylene with hybrid poplars, Environ. Health Perspect. 106(suppl. 4), 1001, 1998.

82. Gotfredson, M., and Gerdes, K. The Escherichia coli relBE genes belong to a new toxin-antitoxin gene family, Mol. Microbiol. 29, 1065, 1998.

83. Graupner, S., and Wackernagel, W. A broad-host-range expression vector series including Ptac test plasmid and its application in the expression of the dod gene of Serratia marcescens (coding for ribulose-5-phosphate 3-epimerase) in Pseudomonas stutzeri, Biomol. Eng. 17, 11, 2000.

84. Gu, A.Z., Hedlund, B.P., Staley, J.T., Strand, S.E., and Stensel, H.D. Analysis and comparison of the microbial community structures of two enrichment cultures capable of reductively dechlorinating TCE and cis-DCE, Environ. Microbiol. 6, 45, 2004.

85. Gugerli, R., Cantana, E., Heinzen, C., von Stockar, U., and Marison, I.W. Quantitative study of the production and properties of alginate/poly-L-lysine microcapsules, J. Microencapsulation 19, 571, 2002.

86. Haby, P.A., and Crowley, D.E. Biodegradation of 3-chlorobenzoate as affected by rhizodeposition and selected carbon substrates, J. Environ. Qual. 25, 304, 1996.

87. Hajji, K.T., Lépine, F., Bisaillon, J.-G., Beaudet, R., Hawari, J., and Guiot, S.R. Effects of bioaugmentation strategies in UASB reactors with a methanogenic consortium for removal of phenolic compounds, Biotechnol. Bioeng. 67, 417, 2000.

88. Hamid, M., Siddiqui, I.A., and Shahid Shaukat, S. Improvement of Pseudomonas fluorescens $\mathrm{CHA} 0$ biocontrol activity against root-knot nematode by the addition of ammonium molybdate, Lett. Appl. Microbiol. 36, 239, 2003.

89. Harkness, M.R., Bracco, A.A., Brennan, M.J., Jr., Deweerd, K.A., and Spivack, J.L. Use of bioaugmentation to stimulate complete reductive dechlorination of trichloroethene in dover soil columns, Environ. Sci. Technol. 33, 1100, 1999.

90. Heid, C.A., Stevens, J., Livak, K.J., and Williams, P.M. Real time quantitative PCR, Genome Res. 6, 986, 1996.

91. Hendrickson, E.R., Payne, J.A., Young, R.M., Starr, M.G., Perry, M.P., Fahnestock, S., Ellis, D.E., and Ebersole, R.C. Molecular analysis of Dehalococcoides $16 \mathrm{~S}$ ribosomal DNA from chloroethene-contaminated sites throughout North America and Europe, Appl. Environ. Microbiol. 68, 485, 2002.

92. Herrero, M., de Lorenzo, V., and Timmis, K.N. Transposon vectors containing non-antibiotic resistance selection markers for cloning and stable chromosomal insertion of foreign genes in Gram-negative bacteria, J. Bacteriol. 172, 6557, 1990.

93. Herrick, J.B., Stuart-Keil, K.G., Ghiorse, W.C., and Madsen, E.L. Natural horizontal transfer of a naphthalene dioxygenase gene between bacteria native to a coal tar-contaminated field site, Appl. Environ. Microbiol. 63, 2330, 1997. 
94. Hestbjerg, H., Willumsen, P.A., Christensen, M., Andersen, O., and Jacobsen, C.S. Bioaugmentation of tar-contaminated soils under field conditions using Pleurotus ostreatus refuse from commercial mushroom production, Environ. Toxicol. Chem. 22, 692, 2003.

95. Hoang, T.T., Kutchma, A.J., Becher, A., and Schweizer, H.P. Integrationproficient plasmids for Pseudomonas aeruginosa: Site-specific integration and use for engineering of reporter and expression strains, Plasmid 43, 59, 2000.

96. Holden, P.A., LaMontagne, M.G., Bruce, A.K., Miller, W.G., and Lindow, S.E. Assessing the role of Pseudomonas aeruginosa surface-active gene expression in hexadecane biodegradation in sand, Appl. Environ. Microbiol. 68, 2509, 2002.

97. Hong, K.J., Tokunaga, S., and Kajiuchi, T. Evaluation of remediation process with plant-derived biosurfactant for recovery of heavy metals from contaminated soils, Chemosphere 49, 379, 2002.

98. Hooker, B.S., and Skeen, R.S. Transgenic phytoremediation blasts onto the scene, Nat. Biotechnol. 17, 428, 1999.

99. Hristova, K.R., Lutenegger, C.M., and Scow, K.M. Detection and quantification of methyl tert-butyl ether-degrading strain PM1 by real-time TaqMan PCR, Appl. Environ. Microbiol. 67, 5154, 2001.

100. Hurt, R.A., Qiu, X., Wu, L., Roh, Y., Palumbo, A.V., Tiedje, J.M., and Zhou, J. Simultaneous recovery of RNA and DNA from soils and sediments, Appl. Environ. Microbiol. 67, 4495, 2001.

101. Jensen, L.B., Ramos, J.-L., Kaneva, Z., and Molin, S. A substrate-dependent biological containment system for Pseudomonas putida based on the Escherichia coli gef gene, Appl. Environ. Microbiol. 59, 3713, 1993.

102. Jernberg, C., and Jansson, J.K. Impact of 4-chlorophenol contamination and/or inoculation with the 4-chlorophenol-degrading strain, Arthrobacter chlorophenolicus A6L, on soil bacterial community structure, FEMS Microbiol. Ecol. 42, 387, 2002.

103. Jitnuyanont, P., Sayavedra-Soto, L.A., and Semprini, L. Bioaugmentation of butane-utilizing microorganisms to promote cometabolism of 1,1,1trichloroethane in groundwater microcosms, Biodegradation 12, 11, 2001.

104. Jones, R.W., Pettit, R.E., and Taber, R.A. Lignite and stillage: Carrier and substrate for application of fungal biocontrol agents to soil, Phytopathology 74, 1167, 1984.

105. Kaplan, D.L., Mello, C., Sano, T., Cantor, C., and Smith, C. Streptavidin-based containment systems for genetically engineered microorganisms, Biomol. Eng. 16, 135, 1999.

106. Karthikeyan, R., and Kulakow, P.A. Soil plant microbe interactions in phytoremediation, Adv. Biochem. Eng. Biotechnol. 78, 51, 2003.

107. Kay, E., Vogel, T.M., Bertolla, F., Nalin, R., and Simonet, P. In situ transfer of antibiotic resistance genes from transgenic (transplastomic) tobacco plants to bacteria, Appl. Environ. Microbiol. 68, 3345, 2002.

108. Kikuchi, T., Iwasaki, K., Nishihara, H., Takamura, Y., and Yagi, O. Quantitative and rapid detection of the trichloroethylene-degrading bacterium Methylocystis sp. M in groundwater by real-time PCR, Appl. Microbiol. Biotechnol. 59, 731, 2002. 
109. Kloos, D.U., Stratz, M., Guttler, A., Steffan, R.J., and Timmis, K.N. Inducible cell lysis system for the study of natural transformation and environmental fate of DNA released by cell death, J. Bacteriol. 176, 7352, 1994.

110. Knudsen, S., Saadbye, P., Hansen, L.H., Collier, A., Jacobsen, B.L., Schlundt, J., and Karlström, O.H. Development and testing of improved suicide functions for biological containment of bacteria, Appl. Environ. Microbiol. 61, 985, 1995.

111. Koch, B., Jensen, L.E., and Nybroe, O. A panel of Tn7-based vectors for insertion of the $g f p$ marker gene or for delivery of cloned DNA into Gram-negative bacteria at a neutral chromosomal site, J. Microbiol. Methods 45, 187, 2001.

112. Köhler, S., Belkin, S., and Schmid, R.D. Reporter gene bioassays in environmental analysis, Fresenius. J. Anal. Chem. 366, 769, 2000.

113. Kok, C.J., Hageman, P.E.J., Maas, P.W.T., Postma, J., Roozen, N.J.M., and van Vuurde, J.W.L. Processed manure as carrier to introduce Trichoderma harzianum: Population dynamics and biocontrol effects on Rhizoctonia solani, Biocontrol Sci. Technol. 6, 147, 1996.

114. Kota, M., Daniell, H., Varma, S., Garczynski, S.F., Gould, F., and Moar, W.J. Overexpression of the Bacillus thuringiensis (Bt) Cry2Aa2 protein in chloroplasts confers resistance to plants against susceptible and Bt-resistant insects, Proc. Natl. Acad. Sci. USA 96, 1840, 1999.

115. Kowalchuk, G.A., Buma, D.S., de Boer, W., Klinkhamer, P.G.L., and van Veen, J.A. Effects of above-ground plant species composition and diversity on the diversity of soil-borne microorganisms, Antonie van Leeuwenhoek 81, 509, 2002.

116. Krutz, L.J., Beyrouty, C.A., Gentry, T.J., Wolf, D.C., and Reynolds, C.M. Selective enrichment of a pyrene degrader population and enhanced pyrene degradation in bermudagrass rhizosphere, Biol. Fert. Soils. 2004(submitted).

117. Kuiper, I., Kravchenko, L.V., Bloemberg, G.V., and Lugtenberg, B.J. Pseudomonas putida strain PCL1444, selected for efficient root colonization and naphthalene degradation, effectively utilizes root exudate components, Mol. Plant Microbe Interact. 15, 734, 2002.

118. Lamar, R.T., Davis, M.W., Dietrich, D.M., and Glaser, J.A. Treatment of a pentachlorophenol- and creosote-contaminated soil using the lignin-degrading fungus Phanerochaete sordida: A field demonstration, Soil Biol. Biochem. 26, 1603, 1994.

119. Lamar, R.T., and Dietrich, D.M., In situ depletion of pentachlorophenol from contaminated soil by Phanerochaete spp., Appl. Environ. Microbiol. 56, 3093, 1990.

120. Lamar, R.T., Schoenike, B., Vanden Wymelenberg, A., Stewart, P., Dietrich, D.M., and Cullen, D. Quantitation of fungal mRNAs in complex substrates by reverse transcription PCR and its application to Phanerochaete chrysosporiumcolonized soil, Appl. Environ. Microbiol. 61, 2122, 1995.

121. Lane, D.J., Pace, B., Olsen, G.J., Stahl, D.A., Sogin, M.L., and Pace, N.R. Rapid determination of $16 \mathrm{~S}$ ribosomal RNA sequences for phylogenetic analyses, Proc. Natl. Acad. Sci. USA 82, 6955, 1985.

122. Lappin-Scott, H.M., and Costerton, J.W. Ultramicrobacteria and their biotechnological applications, Curr. Opin. Biotechnol. 3, 283, 1992.

123. Laramee, L., Lawrence, J.R., and Greer, C.W. Molecular analysis and development of $16 \mathrm{~S}$ rRNA oligonucleotide probes to characterize a 
diclofop-methyl-degrading biofilm consortium, Can. J. Microbiol. 46, 133, 2000.

124. Lassner, M.W., and McElroy, D. Directed molecular evolution: Bridging the gap between genomics leads and commercial products, OMICS 6, 153, 2002.

125. Lau, P.C.K., and de Lorenzo, V. Genetic engineering: The frontier of bioremediation, Environ. Sci. Technol. 33, 124A, 1999.

126. Lawford, H.G., and Rousseau, J.D. Cellulosic fuel ethanol: Alternative fermentation process designs with wild-type and recombinant Zymomonas mobilis, Appl. Biochem. Biotechnol. 105-108, 457, 2003.

127. Leeson, A., and Alleman, B.C. Eds. Phytoremediation and Innovative Strategies for Specialized Remedial Applications, p. 340. Battelle Press, Columbus, OH, 1999.

128. Lehrbach, P.R., Zeyer, J., Reineke, W., Knackmuss, H.-J., and Timmis, K.N. Enzyme recruitment in vitro: Use of cloned genes to extend the range of haloaromatics degraded by Pseudomonas sp. strain B13, J. Bacteriol. 158, 1025, 1984.

129. Lendvay, J.M., Löffler, F.E., Dollhopf, M., Aiello, M.R., Daniels, G., Fathepure, B.Z., Gebhard, M., Heine, R., Helton, R., Shi, J., Krajmalnik-Brown, R., Major, C.L., Jr., Barcelona, M.J., Petrovskis, E., Hickey, R., Tiedje, J.M., and Adriaens, P. Bioreactive barriers: A comparison of bioaugmentation and biostimulation for chlorinated solvent remediation, Environ. Sci. Technol. 37, 1422, 2003.

130. Leveau, J.H.J., and Lindow, S.E. Bioreporters in microbial ecology, Curr. Opin. Microbiol. 5, 259, 2002.

131. Li, Q., and Logan, B.E. Enhancing bacterial transport for bioaugmentation of aquifers using low ionic strength solutions and surfactants, Water Res. 33, 1090, 1999.

132. Loh, J., Pierson, E.A., Pierson, L.S., III, Stacey, G., and Chatterjee, A. Quorum sensing in plant-associated bacteria, Curr. Opin. Plant Biol. 5, 1, 2002.

133. Mae, A., Montesano, M., Koiv, V., and Palva, E.T. Transgenic plants producing the bacterial pheromone $N$-acyl-homoserine lactone exhibit enhanced resistance to the bacterial phytopathogen Erwinia carotovora, Mol. Plant Microbe Interact. 14, 1035, 2001.

134. Maier, R.M., Neilson, J.W., Artiola, J.F., Jordan, F.L., Glenn, E.P., and Descher, S.M. Remediaton of metal-contaminated soil and sludge using biosurfactant technology, Int.J. Occup. Med. Environ. Health 14, 241, 2001.

135. Major, D.W., McMaster, M. L., Cox, E.E., Edwards, E.A., Dworatzek, S.M., Hendrickson, E.R., Starr, M.G., Payne, J.A., and Buonamici, L.W. Field demonstration of successful bioaugmentation to achieve dechlorination of tetrachloroethene to ethene, Environ. Sci. Technol. 36, 5106, 2002.

136. Marlowe, E.M., Wang, J.M., Pepper, I.L., and Maier, R.M. Application of a reverse transcription- PCR assay to monitor regulation of the catabolic nahAc gene during phenanthrene degradation, Biodegradation 13, 251, 2002.

137. Mata-Sandoval, J.C., Karns, J., and Torrents, A. Influence of rhamnolipids and Triton X-100 on the desorption of pesticides from soils, Environ. Sci. Technol. 36, 4669, 2002.

138. Meharg, A.A., and Cairney, J.W.G. Ectomycorrhizas-Extending the capabilities of rhizosphere remediation?, Soil Biol. Biochem. 32, 1475, 2000. 
139. Meharg, A.A., Cairney, J.W.G., and Maguire, N. Mineralization of 2,4dichlorophenol by ectomycorrhizal fungi in axenic culture and in symbiosis with pine, Chemosphere 34, 2495, 1997.

140. Meharg, A.A., and Macnair, M.R. Genetic correlation between arsenate tolerance and the rate of influx of arsenate and phosphate in Holcus lanatus L., Heredity 69, 336, 1992.

141. Middeldorp, P.J.M., Briglia, M., and Salkinoja-Salonen, M.S. Biodegradation of pentachlorophenol in natural soil by inoculated Rhodococcus chlorophenolicus, Microb. Ecol. 20, 123, 1990.

142. Miethling, R., Wieland, G., Backhaus, H., and Tebbe, C.C. Variation of microbial rhizosphere communities in response to crop species, soil origin, and inoculation with Sinorhizobium meliloti L33, Microb. Ecol. 41, 43, 2000.

143. Misko, A.L., and Germida, J.J. Taxonomic and functional diversity of pseudomonads isolated from the roots of field-grown canola, FEMS Microbiol. Ecol. 42, 399, 2002.

144. Molin, S. Environmental potential of suicide genes, Curr. Opin. Biotechnol. 4, 299, 1993.

145. Molin, S., and Givskov, M. Application of molecular tools for in situ monitoring of bacterial growth activity, Environ. Microbiol. 1, 383, 1999.

146. Molina, L., Ramos, C., Ronchel, M.-C., Molin, S., and Ramos, J.-L. Construction of an efficient biologically contained Pseudomonas putida strain and its survival in outdoor assays, Appl. Environ. Microbiol. 64, 2072, 1998.

147. Monib, M., Abd-el-Malek, Y., Hosny, I., and Fayez, M. Effect of Azotobacter inoculation on plant growth and soil nitrogen, Zentralbl. Bakteriol. Naturwiss. 134, 140, 1979.

148. Morrissey, J.P., Walsh, U.F., O’Donnell, A., Moënne-Loccoz, Y., and O'Gara, F. Exploitation of genetically modified inoculants for industrial ecology applications, Antonie van Leeuwenboek 81, 599, 2002.

149. Moslemy, P., Neufeld, R.J., and Guiot, S.R. Biodegradation of gasoline by gellan gum-encapsulated bacterial cells, Biotechnol. Bioeng. 80, 175, 2002.

150. Moslemy, P., Neufeld, R.J., Millette, D., and Guiot, S.R. Transport of gellan gum microbeads through sand: An experimental evaluation for encapsulated cell bioaugmentation, J. Environ. Manage. 69, 249, 2003.

151. Moter, A., and Gobel, U.B. Fluorescence in situ hybridization (FISH) for direct visualization of microorganisms, J. Microbiol. Methods 41, 85, 2000.

152. Mueller, J.G., Resnick, S.M., Shelton, M.E., and Pritchard, P.H. Effect of inoculation on the biodegradation of weathered Prudhoe Bay crude oil, J. Indust. Microbiol. 10, 95, 1992.

153. Narasimhan, K., Basheer, C., Bajic, V.B., and Swarup, S. Enhancement of plantmicrobe interactions using a rhizosphere metabolomics-driven approach and its application in the removal of polychlorinated biphenyls, Plant Physiol. 132, 146, 2003.

154. Neilson, J.W., Pierce, S.A., and Maier, R.M. Factors influencing expression of luxCDABE and nab genes in Pseudomonas putida RB1353 (NAH7, pUTK9) in dynamic systems, Appl. Environ. Microbiol. 65, 3473, 1999.

155. Newby, D.T., Gentry, T.J., and Pepper, I.L. Comparison of 2,4dichlorophenoxyacetic acid degradation and plasmid transfer in soil resulting 
from bioaugmentation with two different pJP4 donors, Appl. Environ. Microbiol. 66, 3399, 2000a.

156. Newby, D.T., Josephson, K.L., and Pepper, I.L. Detection and characterization of plasmid pJP4 transfer to indigenous soil bacteria, Appl. Environ. Microbiol. 66, 290, 2000b.

157. Niemi, K., Vuorinen, T., Ernstsen, A., and Häggman, H. Ectomycorrhizal fungi and exogenous auxins influence root and mycorrhiza formation of Scots pine hypocotyl cuttings in vitro, Tree Physiol. 22, 1231, 2002.

158. Normander, B., and Hendriksen, N.B. Effective dose of a microbial inoculant is one to four cells in the rhizosphere, Can.J. Microbiol. 48, 940, 2002.

159. Ochman, H., Lawrence, J.G., and Groisman, E.A. Lateral gene transfer and the nature of bacterial innovation, Nature 405, 299, 2000.

160. Ogawa, N., and Miyashita, K. Recombination of a 3-chlorobenzoate catabolic plasmid from Alcaligenes eutrophus NH9 mediated by direct repeat elements, Appl. Environ. Microbiol. 61, 3788, 1995.

161. Oger, P.M., Mansouri, H., Nesme, X., and Dessaux, Y. Engineering root exudation of Lotus toward the production of two novel carbon compounds leads to the selection of distinct microbial populations in the rhizosphere, Microb. Ecol., published online, available at http://springerlink.metapress.com/openurl. asp?genre=article\&id=doi:10.1007/s00248-003-2012-9, 2003.

162. Ohtsubo, Y., Shimura, M., Delawary, M., Kimbara, K., Takagi, M., Kudo, T., Ohta, A., and Nagata, Y. Novel approach to the improvement of biphenyl and polychlorinated biphenyl degradation activity: Promoter implantation by homologous recombination, Appl. Environ. Microbiol. 69, 146, 2003.

163. Olexa, T.J., Gentry, T.J., Hartel, P.G., Wolf, D.C., Fuhrmann, J.J., and Reynolds, C.M. Mycorrhizal colonization and microbial community structure in the rhizosphere of annual ryegrass grown in pyrene-amended soils, Int. J. Phytoremediation 2, 213, 2000.

164. Olsen, P.E., Rice, W.A., Bordeleau, L.M., Demidoff, A.H., Collins, M.M. Levels and identities of nonrhizobial microorganisms found in commercial legume inoculant made with nonsterile peat carrier, Can.J. Microbiol. 42, 72, 1996.

165. O'Reilley, K.T., and Crawford, R.L. Degradation of pentachlorophenol by polyurethane immobilized Flavobacterium cells, Appl. Environ. Microbiol. 55, 2113, 1989.

166. Patureau, D., Helloin, E., Rustrian, E., Bouchez, T., Delgenes, J.P., and Moletta, R. Combined phosphate and nitrogen removal in a sequencing batch reactor using the aerobic denitrifier, Microvirgula aerodenitrificans, Wat. Res. 35, 189, 2001.

167. Pepper, I.L., Gentry, T.J., Newby, D.T., Roane, T.M., and Josephson, K.L. The role of cell bioaugmentation and gene bioaugmentation in the remediation of co-contaminated soils, Environ. Health Perspect. 110(Suppl. 6), 943, 2002.

168. Perlak, F.J., Oppenhuizen, M., Gustafson, K., Voth, R., Sivasupramaniam, S., Heering, D., Carey, B., Ihrig, R.A., and Roberts, J.K. Development and commercial use of Bollgard ${ }^{\circledR}$ cotton in the USA-Early promises versus today's reality, Plant J. 27, 489, 2001.

169. Pierson, L.S., III, Expanding the club: Engineering plants to talk to bacteria, Trends Plant. Sci. 5, 89, 2000. 
170. Porteous, L.A., Widmer, F., and Seidler, R.J. Multiple enzyme restriction fragment length polymorphism analysis for high resolution distinction of Pseudomonas (sensu stricto) 16S rRNA genes, J. Microbiol. Methods. 51, 337, 2002.

171. Poulsen, L.K., Larsen, N.W., Molin, S., and Andersson, P. A family of genes encoding a cell-killing function may be conserved in all Gram-negative bacteria, Mol. Microbiol. 3, 1463, 1989.

172. Pritchard, P.H. Use of inoculation in bioremediation, Curr. Opin. Biotech. 3, 232, 1992.

173. Quan, X., Shi, H., Wang, J., and Qian, Y. Biodegradation of 2,4-dichlorphenol in sequencing batch reactors augmented with immobilized mixed culture, Chemosphere 50, 1069, 2003.

174. Rahman, K.S., Rahman, T.J., Kourkoutas, Y., Petsas, I., Marchant, R., and Banat, I.M. Enhanced bioremediation of $n$-alkane in petroleum sludge using bacterial consortium amended with rhamnolipid and micronutrients, Bioresour. Technol. 90, 159, 2003.

175. Ramos, H.J., Roncato-Maccari, L.D., Souza, E.M., Soares-Ramos, J.R., Hung, M., and Pedrosa, F.O. Monitoring Azospirillum-wheat interactions using the $g f p$ and gus $A$ genes constitutively expressed from a new broad-host range vector, J. Biotechnol 97, 243, 2002.

176. Ramos, J.L., Stolz, A., Reineke, W., and Timmis, K.N. Altered effector specificities in regulators of gene expression: TOL plasmid $x y l S$ mutants and their use to engineer expansion of the range of aromatics degraded by bacteria, Proc. Natl. Acad. Sci. USA 83, 8467, 1986.

177. Regan, J.M., Oldenburg, P.S., Park, H.D., Harrington, G.W., and Noguera, D.R. Simultaneous determination of bacterial viability and identity in biofilms using ethidium monoazide and fluorescent in situ hybridization, Water Sci. Technol. 47, 123, 2003.

178. Rensing C., Newby D.T., and Pepper I.L. The role of selective pressure and selfish DNA in horizontal gene transfer and soil microbial community adaptation, Soil. Biol. Biochem. 34, 285, 2002.

179. Richardson, R.E., Bhupathiraju, V.K., Song, D.L., Goulet, T.A., and AlvarezCohen, L. Phylogenetic characterization of microbial communities that reductively dechlorinate TCE based upon a combination of molecular techniques, Environ. Sci. Technol. 36, 2652, 2002.

180. Ripp, S., Nivens, D.E., Ahn, Y., Werner, C., Jarrell, J. IV., Easter, J.P., Cox, C.D., Burlage, R.S., and Sayler, G.S. Controlled field release of a bioluminescent genetically engineered microorganism for bioremediation process monitoring and control, Environ. Sci. Technol. 34, 846, 2000.

181. Roane, T.M., Josephson, K.L., and Pepper, I.L. Dual-bioaugmentation strategy to enhance remediation of cocontaminated soil, Appl. Environ. Microbiol. 67, 3208, 2001.

182. Rodrigues, J.L.M., Aiello, M.R., Urbance, J.W., Tsoi, T.V., and Tiedje, J.M. Use of both 16S rRNA and engineered functional genes with real-time PCR to quantify an engineered, PCB-degrading Rhodococcus in soil, J. Microbiol. Methods 51, 181, 2002.

183. Ronchel, M.C., Molina, L., Witte, A., Lutbiz, W,. Molin, S., Ramos, J.L., and Ramos, C. Characterization of cell lysis in Pseudomonas putida induced upon 
expression of heterologous killing genes, Appl. Environ. Microbiol. 64, 4904, 1998.

184. Ronchel, M.C., and Ramos, J.L. Dual system to reinforce biological containment of recombinant bacteria designed for rhizoremediation, Appl. Environ. Microbiol. 67, 2649, 2001.

185. Ronchel, M.C., Ramos, C., Jensen, L.B., Molin, S., and Ramos, J.L. Construction and behavior of biologically contained bacteria for environmental applications in bioremediation, Appl. Environ. Microbiol. 61, 2990, 1995.

186. Rose, P., Harkin, J.M., and Hickey, W.J. Competitive touchdown PCR for estimation of Escherichia coli DNA recovery in soil DNA extraction, J. Microbiol. Methods 52, 29, 2003.

187. Rosochacki, S.J., and Matejczyk, M. Green fluorescent protein as a molecular marker in microbiology, Acta. Microbiol. Pol. 51, 205, 2002.

188. Ross, N., Villemur, R., Marcandella, É., and Deschênes, L. Assessment of changes in biodiversity when a community of ultramicrobacteria isolated from groundwater is stimulated to form a biofilm, Microb. Ecol. 42, 56, 2001.

189. Runes, H.B., Jenkins, J.J., and Bottomley, P.J. Atrazine degradation by bioaugmented sediment from constructed wetlands, Appl. Microbiol. Biotechnol. 57, 427, 2001.

190. Rutledge, R.G., and Cote, C. Mathematics of quantitative kinetic PCR and the application of standard curves, Nucleic Acids Res. 31, e93, 2003.

191. Salanitro, J.P., Johnson, P.C., Spinnler, G.E., Maner, P.M., Wisniewski, H.L., and Bruce, C. Field-scale demonstration of enhanced MTBE bioremediation through aquifer bioaugmentation and oxygenation, Environ. Sci. Technol. 34, 4152, 2000.

192. Sambrook, J., and Russell, D. Molecular Cloning-A Laboratory Manual, 3rd ed., Cold Spring Harbor Laboratory, Cold Spring Harbor, NY, 2001, 2344.

193. Sandrin, T.R., Chech, A.M., and Maier, R.M. A rhamnolipid biosurfactant reduces cadmium toxicity during naphthalene biodegradation, Appl. Environ. Microbiol. 66, 4585, 2000.

194. Savka, M.A., Dessaux, Y., Oger, P., and Rossbach, S. Engineering bacterial competitiveness and persistence in the phytosphere, Mol. Plant Microbe Interact. 15, 866, 2002.

195. Savka, M.A., and Farrand, S.K. Modification of rhizobacterial populations by engineering bacterium utilization of a novel plant-produced resource, Nat. Biotechnol. 15, 363, 1997.

196. Sayler, G.S., Fleming, J.T., and Nivens, D.E. Gene expression monitoring in soils by mRNA analysis and gene lux fusions, Curr. Opin. Biotechnol. 12, 455, 2001.

197. Sayler, G.S., and Ripp, S. Field applications of genetically engineered microorganisms for bioremediation processes, Curr. Opin. Biotechnol. 11, 286, 2000.

198. Scheel, T., Hofer, M., Ludwig, S., and Holker, U. Differential expression of manganese peroxidase and laccase in white-rot fungi in the presence of manganese or aromatic compounds, Appl. Microbiol. Biotechnol. 54, 686, 2000.

199. Schippers, C., Gessner, K., Muller, T., and Scheper, T. Microbial degradation of phenanthrene by addition of a sophorolipid mixture, J. Biotechnol. 83, 189, 2000. 
200. Schwartz, E., and Scow, K.M. Repeated inoculation as a strategy for the remediation of low concentrations of phenanthrene in soil, Biodegradation 12, 201, 2001.

201. Schweizer, H.P. Vectors to express foreign genes and techniques to monitor gene expression in Pseudomonads, Curr. Opin. Biotechnol. 12, 439, 2001.

202. Schwieger, F., and Tebbe, C.C. Effect of field inoculation with Sinorbiobium meliloti $\mathrm{L} 33$ on the composition of bacterial communities in rhizospheres of a target plant (Medicago sativa) and a non-target plant (Chenopodium album) Linking of $16 \mathrm{~S}$ rRNA gene-based single-strand conformation polymorphism community profiles to the diversity of cultivated bacteria, Appl. Environ. Microbiol. 66, 3556, 2000.

203. Sefton, M.V., Dawson, R.M., Broughton, R.L., Blysniuk, J., and Sugamori, M.E. Microencapsulation of mammalian cells in a water-soluble polyacrylate by coextrusion and interfacial precipitation, Biotechnol. Bioeng. 29, 1135, 1987.

204. Sekelsky, A.M., and Shreve, G.S. Kinetic model of biosurfactant-enhanced hexadecane biodegradation by Pseudomonas aeruginosa, Biotechnol. Bioeng. 63, 401, 1999.

205. Sessitsch, A., Gyamfi, S., Stralis-Pavese, N., Weilharter, A., and Pfeifer, U. RNA isolation from soil for bacterial community and functional analysis: Evaluation of different extraction and soil conservation protocols, J. Microbiol. Methods 51, 171, 2002.

206. Sheeja, R.Y., and Murugesan, T. Mass transfer studies on the biodegradation of phenols in up-flow packed bed reactors, J. Hazard. Mater. B89, 287, 2002.

207. Shimizu, M., Kimura, T., Koyama, T., Suzuki, K., Ogawa, N., Miyashita, K., Sakka, K., and Ohmiya, K. Molecular breeding of transgenic rice plants expressing a bacterial chlorocatechol dioxygenase gene, Appl. Environ. Microbiol. 68, 4061, 2002.

208. Siciliano, S.D., and Germida, J.J. Bacterial inoculants of forage grasses that enhance degradation of 2-chlorobenzoic acid in soil, Environ. Toxicol. Chem. 16, 1098, 1997.

209. Siciliano, S.D., and Germida, J.J. Biolog analysis and fatty acid methyl ester profiles indicate that pseudomonad inoculants that promote phytoremediation alter the root-associated microbial community of Bromus biebersteinii, Soil Biol. Biochem. 30, 1717, 1998.

210. Siciliano, S.D., and Germida, J.J. Degradation of chlorinated benzoic acid mixtures by plant-bacterial associations, Environ. Toxicol. Chem. 17, 728, 1998.

211. Siciliano, S.D., and Germida, J.J. Taxonomic diversity of bacteria associated with the roots of field-grown transgenic Brassica napus cv. Quest, compared to the non-transgenic B. napus cv. Excel and B. rapa cv. Parkland, FEMS Microbiol. Ecol. 29, 263, 1999.

212. Siciliano, S.D., and Greer, C.W. Plant-bacterial combinations to phytoremediate soil contaminated with high concentrations of 2,4,6-trinitrotoluene, J. Environ. Qual. 29, 311, 2000.

213. Sidhu, R.S., Hammond, B.G., Fuchs, R.L., Mutz, J.-N., Holden, L.R., George, B., and Olson, T. Glyphosate-tolerant corn: The composition and feeding value of grain from glyphosate-tolerant corn is equivalent to that of conventional corn (Zea mays L.), J. Agric. Food Chem. 48, 2305, 2000. 
214. Silva, E., Fialho, A.M., Sa-Correia, I., Burns, R.G., and Shaw, L.J. Combined bioaugmentation and biostimulation to cleanup soil contaminated with high concentrations of atrazine, Environ. Sci. Technol. 38, 632, 2004.

215. Singer, A.C., Smith, D., Jury, W.A., Hathuc, K., and Crowley, D.E. Impact of the plant rhizosphere and augmentation on remediation of polychlorinated biphenyl contaminated soil, Environ. Toxicol. Chem. 22, 1998, 2003.

216. Smit, E., Wolters, A.C., Lee, H., Trevors, J.T., and van Elsas, J.D. Interactions between a genetically marked Pseudomonas fluorescens strain and bacteriophage $\Phi$ R2f in soil: Effects of nutrients, alginate encapsulation, and the wheat rhizosphere, Microb. Ecol. 31, 125, 1996.

217. Springael, D., Diels, L., Hooyberghs, L., Kreps, S., and Mergeay, M. Construction and characterization of heavy metal-resistant haloaromatic-degrading $\mathrm{Al}$ caligenes eutrophus strains, Appl. Environ. Microbiol. 59, 334, 1993.

218. Steffan, R.J., Sperry, K.L., Walsh, M.T., Vainberg, S., and Condee, C.W. Field-scale evaluation of in situ bioaugmentation for remediation of chlorinated solvents in groundwater, Environ. Sci. Technol. 33, 2771, 1999.

219. Steidle, A., Sigl, K., Schuhegger, R., Ihring, A., Schmid, M., Gantner, S., Stoffels, M., Riedel, K., Givskov, M., Hartmann, A., Langebartels, C., and Eberl, L. Visualization of $N$-acylhomoserine lactone-mediated cell-cell communication between bacteria colonizing the tomato rhizosphere, Appl. Environ. Microbiol. 67, 5761, 2001.

220. Steinberg, S.M., Poziomek, E.J., Engelmann, W.H., and Rogers, K.R. A review of environmental applications of bioluminescence measurements, Chemosphere, 30, 2155, 1995.

221. Steinle, P., Thalmann, P., Höhener, P., Hanselmann, K.W., and Stucki, G. Effect of environmental factors on the degradation of 2,6-dichlorophenol in soil, Environ. Sci. Technol. 34, 771, 2000.

222. Streger, S.H., Vainberg, S., Dong, H., and Hartzinger, P.B., Enhancing transport of Hydrogenophaga flava ENV735 for bioaugmentation of aquifers contaminated with methyl tert-butyl ether, Appl. Environ. Microbiol. 68, 5571, 2002.

223. Strong, L.C., McTavish, H., Sadowsky, M.J., and Wackett, L.P. Field-scale remediation of atrazine-contaminated soil using recombinant Escherichia coli expressing atrazine chlorohydrolase, Environ. Microbiol. 2, 91, 2000.

224. Stutzman-Engwall, K., Conlon, S., Fedechko, R., Kaczmarek, F., McArthur, H., Krebber, A., Chen, Y., Minshull, J., Raillard, S.A., and Gustafsson, C. Engineering the aveC gene to enhance the ratio of doramectin to its CHC-B2 analogue produced in Streptomyces avermitilis, Biotechnol. Bioeng. 82, 359, 2003.

225. Suenaga, H., Goto, M., and Furukawa, K. Emergence of multifunctional oxygenase activities by random priming recombination, J. Biol. Chem. 276, 22500, 2001.

226. Szafranski, P., Mello, C.M., Sano, T., Smith, C.L., Kaplan, D.L., and Cantor, C.R. A new approach for containment of microorganisms: Dual control of streptavidin expression of antisense RNA and the T7 transcription system, Proc. Natl. Acad. Sci. USA 94, 1059, 1997.

227. Taylor, C.C., Ranjit, N.J., Mills, J.A., Neylon, J.M., and Kung, L. Jr. The effect of treating whole-plant barley with Lactobacillus buchneri 40788 on silage 
fermentation, aerobic stability, and nutritive value for dairy cows, J. Dairy Sci. 85, 1793, 2002.

228. Temprano, F.J., Albareda, M., Camacho, M., Daza, A., Santamaria, C., and Rodriguez-Navarro, D.N. Survival of several Rhizobium/Bradyrhizobium strains on different inoculant formulations and inoculated seeds, Int. Microbiol. 5, 81, 2002.

229. Teplitski, M., Robinson, J.B., and Bauer, W.D. Plants secrete substances that mimic bacterial $\mathrm{N}$-acyl homoserine lactone signal activities and affect population density-dependent behaviors in associated bacteria, Mol. Plant Microbe Interact. 13, 637, 2000.

230. Thiem, S.M., Krumme, M.L., Smith, R.L., and Tiedje, J.M. Use of molecular techniques to evaluate the survival of a microorganism injected into an aquifer, Appl. Environ. Microbiol. 60, 1059, 1994.

231. Thomas, J.C., Davies, E.C., Malick, F.K., Endreszl, C., Williams, C.R., Abbas, M., Petrella, S., Swisher, K., Perron, M., Edwards, R., Ostenkowski, P., Urbanczyk, N., Wiesend, W.N., and Murray, K.S. Yeast metallothionein in transgenic tobacco promotes copper uptake from contaminated soils, Biotechnol. Prog. 19, 273, 2003.

232. Thurnheer, T., Gmur, R., and Guggenheim, B. Multiplex FISH analysis of a six-species bacterial biofilm, J. Microbiol. Methods. 56, 37, 2004.

233. Top, E.M., Maila, M.P., Clerinx, M., Goris, J., De Vos, P., and Verstraete, W. Methane oxidation as a method to evaluate the removal of 2,4dichlorophenoxyacetic acid (2,4-D) from soil by plasmid mediated bioaugmentation, FEMS Microb. Ecol. 28, 203, 1999.

234. Top, E.M., Springael, D., and Boon, N. Catabolic mobile genetic elements and their potential use in bioaugmentation of polluted soil and waters, FEMS Microb. Ecol. 42, 199, 2002.

235. Top, E.M., Van Daele, P., De Saeyer, N., and Forney, L.J. Enhancement of 2,4dichlorophenoxyacetic acid (2,4-D) degradation in soil by dissemination of catabolic plasmids, Antonie Van Leeuwenhoek. 73, 87, 1998.

236. Trevors, J.T., van Elsas, J.D., Lee, H., and van Overbeek, L.S. Use of alginate and other carriers for encapsulation of microbial cells for use in soil, Microb. Releases 1, 61, 1992.

237. Unge, A., Tombolini, R., Mølbak, L., and Jansson, J.K. Simultaneous monitoring of cell number and metabolic activity of specific bacterial populations with a dual gfp-luxAB marker system, Appl. Environ. Microbiol. 65, 813, 1999.

238. U.S. EPA, Biotechnology Program Under Toxic Substances Control Act (TSCA), Notifications, FY98 to Present [Online], available at http://www.epa.gov/ opptintr/biotech/submiss.htm, 2003 (verified 14 February 2004).

239. U.S. EPA, Microbial Products of Biotechnology; Final Regulation Under the Toxic Substances Control Act [Online], available at http://www.epa.gov/fedrgstr/ EPA-TOX/1997/April/Day-11/t8669.htm, 1997 (verified 14 February 2004).

240. U.S. EPA, Phytoremediation Resource Guide, Publication 542-B-99-003, 1999.

241. van der Gast, C.J., Whiteley, A.S., Starkey, M., Knowles, C.J., and Thompson, I.P. Bioaugmentation strategies for remediating mixed chemical effluents, Biotechnol. Prog. 19, 1156, 2003. 
242. Van Dyke, M.I., and Prosser, J.I. Enhanced survival of Pseudomonas fluorescens in soil following establishment of inoculum in a sterile soil carrier, Soil Biol. Biochem. 32, 1377, 2000.

243. van Veen, J.A., van Overbeek, L.S., and van Elsas, J.D. Fate and activity of microorganisms introduced into soil, Microbiol. Mol. Biol. Rev. 61, 121, 1997.

244. Vassilev, N., Vassileva, M., Azcon, R., and Medina, A. Application of free and Ca-alginate-entrapped Glomus deserticola and Yarowia lipolytica in a soil-plant system, J. Biotechnol. 91, 237, 2001.

245. Vogel, T.M. Bioaugmentation as a soil bioremediation approach, Curr. Opin. Biotech. 7, 311, 1996.

246. Wackett, L.P., Sadowsky, M.J., Martinez, B., and Shapir, N. Biodegradation of atrazine and related $s$-triazine compounds: From enzymes to field studies, $A p p l$. Microbiol. Biotechnol. 58, 39, 2002.

247. Wang, G., Gentry, T.J., Grass, G., Josephson, K., Rensing, C., and Pepper, I.L. Real-time PCR quantification of a GFP-labeled, genetically engineered Pseudomonas putida strain during 2-chlorobenzoate degradation in soil, FEMS Microbiol. Lett. 233, 307, 2004.

248. Wantanabe, K., Hino, S., Onodera, K., Kajie, S., and Takahashi, N. Effects of exogenous phenol-degrading bacteria on performance and ecosystem of activated sludge, J. Ferment. Bioeng. 82, 291, 1996.

249. Wantanabe, K., Teramoto, M., and Harayama, S. Stable augmentation of activated sludge with foreign catabolic genes harboured by an indigenous dominant bacterium, Environ. Microbiol. 4, 577, 2002.

250. Weir, S.C., Dupuis, S.P., Providenti, M.A., Lee, H., and Trevors, J.T. Nutrient-enhanced survival of and phenanthrene mineralization by alginateencapsulated and free Pseudomonas sp. UG14Lr cells in creosote-contaminated soil slurries, Appl. Microbiol. Biotechnol. 43, 946, 1995.

251. Weir, S.C., Providenti, M.A., Lee, H., and Trevors, J.T. Effect of alginate encapsulation and selected disinfectants on survival of and phenanthrene mineralization by Pseudomonas sp UG14Lr in creosote-contaminated soil, J. Ind. Microbiol. 16, 62, 1996.

252. Wenderoth, D.F., Rosenbrock, P., Abraham, W.-R., Pieper, D.H., and Höfle, M.G. Bacterial community dynamics during biostimulation and bioaugmentation experiments aiming at chlorobenzene degradation in groundwater, Microb. Ecol. 46, 161, 2003.

253. Whitehead, N.A., Barnard, A.M.L., Slater, H., Simpson, N.J.L., and Salmond, G.P.C. Quorum-sensing in Gram-negative bacteria, FEMS Microbiol. Rev. 25, 365, 2001.

254. Whiting, S.N., de Souza, M.P., and Terry, N. Rhizosphere bacteria mobilize Zn for hyperaccumulation by Thlaspi caerulescens, Environ. Sci. Technol. 35, 3144, 2001.

255. Widada, J., Nojiri, H., Kasuga, K., Yoshida, T., Habe, H., and Omori, T. Quantification of carbazole 1,9a-dioxygenase gene by real-time competitive PCR combined with co-extraction of internal standards, FEMS Microbiol. Lett. 202, 51, 2001.

256. Widada, J., Nojiri, H., Yoshida, T., Habe, H., and Omori, T. Enhanced degradation of carbazole and 2,3-dichlorodibenzo- $p$-dioxin in soils by Pseudomonas resinovorans strain CA10, Chemosphere, 49, 485, 2002. 
257. Winther-Larsen, H.C., Josefsen, K.D., Brautaset, T., and Valla, S. Parameters affecting gene expression from the Pm promoter in gram-negative bacteria, Metab. Eng. 2, 79, 2000.

258. Witt, M.E., Dybas, M.J., Worden, R.M., and Criddle, C.S. Motility-enhanced bioremediation of carbon tetrachloride-contaminated aquifer sediments, Environ. Sci. Technol. 33, 2958, 1999.

259. Wu, L., Thompson, D.K., Li, G., Hurt, R.A., Tiedje, J.M., and Zhou, J. Development and evaluation of functional gene arrays for detection of selected genes in the environment, Appl. Environ. Microbiol. 67, 5780, 2001.

260. Yang, Y., and Zeyer, J. Specific detection of Dehalococcoides species by fluorescence in situ hybridization with $16 \mathrm{~S}$ rRNA-targeted oligonucleotide probes, Appl. Environ. Microbiol. 69, 2879, 2003.

261. Yee, D.C., Maynard, J.A., and Wood, T.K. Rhizoremediation of trichloroethylene by a recombinant, root-colonizing Pseudomonas fluorescens strain expressing toluene ortho-monooxygenase constitutively, Appl. Environ. Microbiol. 64, 112, 1998.

262. Zhao, S., Arthur, E.L., and Coats, J.R. Influence of microbial inoculation (Pseudomonas sp. strain ADP), the enzyme atrazine chlorohydrolase, and vegetation on the degradation of atrazine and metolachlor in soil, J. Agric. Food Chem. 51, 3043, 2003.

263. Zhou, J. Microarrays for bacterial detection and microbial community analysis, Curr. Opin. Microbiol. 6, 288, 2003.

264. Zhou, J., and Thompson, D.K. Challenges in applying microarrays to environmental studies, Curr. Opin. Biotechnol. 13, 204, 2002.

265. Zhou, J.-Z., and Tiedje, J.M. Gene transfer from a bacterium injected into an aquifer to an indigenous bacterium, Mol. Ecol. 4, 613, 1995.

266. Zouboulis, A.I., Loukidou, M.X., and Christodoulou, K. Enzymatic treatment of sanitary landfill leachate, Chemosphere 44, 1103, 2001. 